\title{
Poszttraumás növekedés gyermekkorban daganatos betegségen átesett gyógyult fiatal felnóttek és daganatos betegségen átesett gyermekek szülei körében
}

\author{
ZSIGMOND ORSOLYA ${ }^{1,2 *}$ - RIGÓ ADRIEN ${ }^{2}$ \\ ${ }^{1}$ ELTE Eötvös Loránd Tudományegyetem Pedagógiai és Pszichológiai Kar Pszichológiai \\ Doktori Iskola, Budapest \\ ${ }^{2}$ ELTE Eötvös Loránd Tudományegyetem Pedagógiai és Pszichológiai Kar Pszichológiai \\ Intézet, Budapest
}

(Beérkezett: 2019. január 27.; elfogadva: 2019. május 3.)

Elméleti háttér: A gyermekkori daganatos betegség súlyos, traumatikus élmény a gyermek és szülei számára is. A negatív pszichés tényezők mellett ugyanakkor sok esetben pozitív változások, poszttraumás növekedés (PTN) is megjelenik mind a gyermek, mind a szülő megélésében, ha a gyermek felépül. Cél: Jelen tanulmány célja az volt, hogy feltárjuk a poszttraumás növekedést befolyásoló tényezőket mind a gyógyult fiatal felnőttek, mind a szülök esetében. Módszerek: Retrospektív vizsgálatunkban 53 gyermekkori daganatos betegségen átesett fiatal felnőtt (17 férfi és 36 nő; átlagéletkor: 27,5 év, SD = 5,4 év) és 112 szülő (9 férfi és 103 nő; átlagéletkor: 44,9 év, SD = 6,7 év) vett részt. A demográfiai jellemzők (nem, életkor), a betegségváltozók (diagnózis óta eltelt idő, diagnóziskori életkor, diagnózis kockázata) és a pszichoszociális tényezők (társas támogatás, érzelemszabályozás, pszichológiai jóllét, poszttraumás stressztünetek) kapcsolatát vizsgáltuk a PTN-nel leíró, összehasonlító, korrelációs és lineáris regresszió elemzések segítségével. Eredmények: Az eredmények megerősítették, hogy mind a gyógyult fiatal felnőttek, mind a szülők több mint 90\%-a átélt PTN-t legalább minimális szinten a növekedés legalább egy dimenziójában. A gyógyult fiatal felnőttek csoportjában a társas támogatás, a pszichológiai jóllét, a poszttraumás stressztünetek közül pedig az emlékbetörés és a pozitív érzelmekre vonatkozó elfojtás a PTN varianciájának $50 \%$-át magyarázták. A szülők csoportjában a hyperarousal, az énfókuszú rumináció és a pszichológiai jóllét a PTN varianciájának 26,5\%-át magyarázták. Következtetések: Az eredmények megerősítik, hogy a PTN magyarázatában különböző változók komplex összefüggésben fejtik ki hatásukat. Vizsgálatunk eredményei rámutatnak arra, hogy a klinikai pszichológiai intervenciók tervezése során a betegséggel járó negatív tünetek egyéni kezelése mellett a család bevonása, a szociális tényezők javítása és a különböző kognitív terápiás eszközök is kiemelt jelentőségúek lehetnek a trauma integrálása szempontjából.

Kulcsszavak: poszttraumás növekedés, gyermekkori daganatos betegség, poszttraumás stressztünetek, rumináció, társas támogatás

\footnotetext{
* Levelező szerző: Zsigmond Orsolya, Eötvös Loránd Tudományegyetem, Pedagógiai és Pszichológiai Kar, Pszichológiai Doktori Iskola, ELTE Pszichológiai Intézet, 1064 Budapest, Izabella u. 46. E-mail: alyoosa@gmail.com
} 


\section{Bevezetés}

Az akut traumák - balesetek, természeti katasztrófák stb. - mellett egyre inkább létjogosultságot nyer az a nézet, hogy a krónikus (esetünkben a daganatos) betegségek is lehetnek traumatikus folyamat jellegúek (összefoglaló: Rigó \& Zsigmond, 2015). Ugyanakkor, a daganatos betegségek számos szempontból különböznek az akut traumáktól. Fontos különbség, hogy a stresszor természete tartalmilag komplexebb, az életfenyegetés nem csak a diagnózisra vonatkozik, hanem az esetleges kiújulásra, s a haláltól való félelemre is (Sumalla, Ochoa, \& Blanco, 2009), így jövőbeli irányultságot is feltételez. Amellett, hogy az utóbbi évtizedekben jelentősen megnőtt a túlélési esély a gyermekkori daganatos betegségek tekintetében (az ötéves túlélés $80 \%$, Ward, DeSantis, Robbins, Kohler, \& Jemal, 2014), fontos kiemelni, hogy a gyógyulást követóen is fokozott az esélye az elsődleges daganat kiújulásának, vagy másodlagos daganat képződésének, sőt más krónikus betegség is megjelenhet a daganatos betegség következtében. A betegség és a kezelések emellett maradandó funkcionális károsodásokat (mozgásszervi nehézségek, anyagcsereproblémák, cukorbetegség, látásromlás, stb.) is okozhatnak (Armstrong és mtsai, 2009), amelyek mind további stressznek teszik ki a családot (Ward és mtsai, 2014). Így a gyermekkori daganatos betegség mint tartós stresszforrás jelenik meg a gyermek és családja életében, a kezelések lezárása, sőt a gyógyulás után is (Zsigmond, Rigó, \& Bányai, 2017). Vizsgálatunkban - a szakirodalmi állásfoglalásokkal összhangban (Kazak és mtsai, 2005) - traumatikus élményként tárgyaljuk a súlyos, gyermekkori, daganatos betegséget, nemcsak a gyermek, de a szülők szempontjából is.

A daganatos betegség hatásai - diagnózis, akut fizikai sérülés, kiújulás, hospitalizáció, orvosi beavatkozások stb. (Picoraro, Womer, Kazak, \& Feudtner, 2014) - folytán korábban leginkább deficitszempontú kutatások születtek, középpontban a poszttraumás stressztünetekkel (PTSS), a poszttraumás stressz betegséggel (PTSD), és az ezeket meghatározó tényezőkkel (pl.: Bruce, 2006; Erickson \& Steiner, 2000; Kazak és mtsai, 2004; Yaluğ, Tufan, Doksat, \& Yaluğ, 2011). A traumával kapcsolatos stressztünetek elkerülő viselkedésben, emlékbetörések formájában és megnövekedett arousal szintben (hyperarousal) jelenhetnek meg (Kangas, Henry, \& Bryant, 2002). Egy áttekintó tanulmányban azt találták, hogy a malignus daganattal diagnosztizált gyermekek szüleinél - hangsúlyosabban az édesanyáknál ugyanannyi, vagy akár több poszttraumás stressztünet vagy zavar jelenhet meg, mint a gyermekeknél, vélhetően azért, mert a szülők kognitív kapacitása fejlettebb, így jobban felmérik a betegség objektív életet fenyegető jellegét (Yaluğ és mtsai, 2011).

Annak ellenére, hogy a gyermekkori daganatos betegségek túlélési aránya jelentősen megnőtt, egyelőre kevesebb kutatás foglalkozik a trauma- 
tikus folyamat során átélt negatív pszichés tényezők mellett az esetleges pozitív pszichés változásokkal, a poszttraumás növekedés (PTN) jelenségével. A poszttraumás növekedés a súlyos, életet veszélyeztető tapasztalat során, a traumával való küzdelem talaján születik, s pozitív pszichológiai változást hozhat a személyiség múködésének öt területén: az élet fokozottabb értékelésében, az interperszonális kapcsolatok fejlődésében, a személyes eró fokozottabb érzésében, az új életlehetőségek felismerésében, valamint a spirituális és vallási növekedésben (Tedeschi \& Calhoun, 2004). Calhoun és Tedeschi (2006) funkcionális modellje alapján a poszttraumás növekedés a trauma által keltett distressz, az eddigi alapfeltevések (pl.: „,a világ biztonságos, velem nem történhet meg semmi rossz") és sémák szétesése, és a traumával való kognitív feldolgozási munka hatására jön létre. A trauma kognitív feldolgozását kezdetben automatikus ruminációs folyamatok, a traumával kapcsolatos emlékbetörések, később tudatos ruminációs folyamatok segítik, állandó, de kezelhető stressz szint mellett. A legtöbb traumatikus stressz kezelésére irányuló intervenció ugyanakkor csak a negatív pszichés hatásokat (poszttraumás stressz) igyekszik csökkenteni, a növekedés facilitálása nélkül. A poszttraumás növekedés elméleti keretében azonban komplex ellátást lehetne nyújtani gyermekkori daganatos betegségen átesett fiatal felnótteknek a család bevonásával (Picoraro és mtsai, 2014), így a szülők vizsgálata is különösen fontos. A gyermek gyógyulási folyamatában nagy szerepe van a szülői támogatásnak, amely ugyanakkor a szülő számára is hatalmas pszichés distresszel jár (Bruce, Gumley, Isham, Fhearon, \& Phipps, 2011).

Az utóbbi időszak kutatásai között azonban már találunk példákat a poszttraumás növekedés vizsgálatára gyermekkori daganatos betegségen átesett személyeknél és szüleiknél (pl.: Arpawong, Oland, Milam, Ruccione, \& Meeske, 2013; Barakat, Alderfer, \& Kazak, 2006; Gianinazzi és mtsai, 2016; Kamibeppu és mtsai, 2010; McDonell, Pope, Schuler, \& Ford, 2018; Yi, Zebrack, Kim, \& Cousino, 2015; Zebrack és mtsai, 2015). A gyermekkorukban daganatos betegséget átélt fiatal felnőttek 84-88\%-a átél poszttraumás növekedést, legalább minimális szinten, legalább a növekedés egy területén (Barakat és mtsai, 2006; Yi és mtsai, 2015). A szülők esetében ez az arány 80-90\% (Barakat és mtsai, 2006). Egy másik kutatásban a szülők 62\%-a számolt be közepes mértékú növekedésről, amelynek legerősebb magyarázó változói a diagnózis észlelt súlyossága és a distressz mértéke voltak (Hungerbuehler, Vollrath, \& Landolt, 2011).

A poszttraumás növekedés (PTN) kialakulásában szerepet játszó, s az azt befolyásoló tényezók tekintetében még nem született konszenzus. A gyermekkori daganatos betegséget átélt fiatal felnőttek tekintetében a PTN magyarázó változói között megjelenik a nem (Arpawong és mtsai, 2013; Gianiazzi és mtsai, 2016; Yi és mtsai, 2015) és a diagnóziskori életkor (Barakat és mtsai, 2006; Devine, Reed-Knight, Loiselle, Fenton, \& Blount, 
2010; Yi és mtsai, 2015) is. A fenti kutatások eredményei arra utalnak, hogy a nők és a diagnózis idején idősebb vizsgálati személyek magasabb PTN-t élhetnek át. A különböző betegségváltozók (Arpawong és mtsai., 2013; Devine és mtsai, 2010; Turner-Sack, Menna, \& Setchell, 2012), a kezelés észlelt (Devine és mtsai, 2010) és objektív súlyossága (Barakat és mtsai, 2006), a pszichológiai jóllét (Kamibeppu és mtsai, 2010; Zebrack \& Chesler, 2002) és a poszttraumás stressztünetek (Arpawong és mtsai, 2013; Barakat és mtsai, 2006; Gunst, Kaatsch, \& Goldbeck, 2016) is kapcsolatban lehetnek a PTN-nel. A fenti változókkal kapcsolatos eredmények azonban változatos képet mutatnak, minden prediktor esetében találhatunk példát pozitív irányú kapcsolatra, de a kapcsolat hiányára is a PTN-nel. Ennek hátterében szerepet játszhat, hogy a kutatások eltérő betegségcsoportokat vizsgáltak, és a módszerekben is különböztek (a vizsgált konstruktumokban, az alkalmazott mérőeszközökben és statisztikai módszerekben egyaránt). Mindezek ellenére konzisztens eredménynek túnik, hogy az általános társas támogatás nagyobb mértéke a PTN nagyobb mértékével jár együtt (Ekim \& Ocakci, 2015; Gunst és mtsai, 2016; Yi és mtsai, 2015). Emellett úgy túnik, hogy a pozitív megküzdési stratégiák (úgymint pozitív átkeretezés, elfogadás és aktív-adaptív megküzdés) is pozitív kapcsolatban vannak a PTN-nel (Bussel \& Naus, 2010; Turner Sack és mtsai, 2012). Egy további tanulmány pedig a PTN és rumináció pozitív irányú kapcsolatát mutatta ki (Kilmer \& Gil-Rivas, 2010). A ruminációs folyamatok jelentősége abban állhat, hogy segithetnek jobban megérteni a traumát és könnyebben befogadni a pozitív jelentéstartalmát, amely facilitálja az átélő kognitív sémáinak megváltoztatását a trauma integrálása során (Kilmer, 2006; Tedeschi, Calhoun, \& Cann, 2007). Fontos megjegyezni, hogy egyes kutatások eredményei szerint nemcsak a negatív hatásokkal kapcsolatos érzelemszabályozási, illetve ruminációs folyamatok, hanem a pozitív érzelmekre adott válaszok (például: amikor az illető jól érzi magát, akkor mennyire észleli, hogy tele van energiával vagy mennyire élvezi az adott pillanatot, stb.) is fontosak lehetnek depreszsziós tünetek kialakulása szempontjából (Bijttebier, Raes, Vasej, \& Feldman, 2012; Feldman, Joormann, \& Johnson, 2008). Végül a PTN területeinek vizsgálata során több kutatásban is az élet fokozottabb megbecsülése és az elmélyülő kapcsolatok igénye emelkedett ki gyermekkori daganatos betegséget túlélt fiatal felnőttek csoportjában (Gianiazzi és mtsai, 2016; Yi és mtsai, 2015).

A daganatos betegséget túléló gyermekek szülei esetében a poszttraumás növekedés magyarázó változóinak vizsgálata alulreprezentált (Picoraro és mtsai, 2014), így feltárásuk hiánypótló. A néhány publikált tanulmány közül az egyik pozitív irányú kapcsolatot jelzett a szüló poszttraumás növekedése és a kezelés alatti szorongása között (Best, Streisand, Catania, \& Kazak, 2001), tehát minél magasabb szorongásszintről számolt be a szülő, annál fokozottabb volt a poszttraumás növekedése. Egy másik tanulmányban a 
poszttraumás növekedés varianciájának 34\%-át magyarázta a családi kapcsolatok minősége, az átélt distressz mértéke, a szülő neme és a diagnózis fajtája (Hungerbuehler és mtsai, 2011). Tehát, minél erősebb distresszt élt át a szülő, minél súlyosabb volt a gyermek diagnózisa és minél jobbak voltak a családi kapcsolatok, annál fokozottabb volt a poszttraumás növekedés, amelyet tovább erősített, hogyha a szülő nőnemú volt. A szülők szempontjából fontos megemlíteni az úgynevezett vikariáló (behelyettesító) poszttraumás növekedés jelenségét. Daganatos betegségen átesett személyek és élettársuk esetében azt találták, hogy a támaszt nyújtó társ közvetett módon átélheti a traumát és ezzel párhuzamosan a poszttraumás növekedést is, de kissé alacsonyabb szinten, mint a traumát elszenvedő fél (Manne és mtsai, 2004; Zwahlen, Hagenbuch, Carley, Jenewein, \& Buchi, 2010). A trauma kognitív és érzelmi feldolgozásának elsődleges facilitálói a közeli hozzátartozók, így daganatos gyermekek esetében a szülők. Azonban véleményünk szerint a szülők számára a gyermek daganatos betegsége elsődleges traumának tekinthető, amelyet a gyermek traumájának közvetett átélése még intenzívebbé tesz. A gyermek életveszélyes betegsége a szülő szempontjából a DSM-IV diagnosztikus kategóriarendszer alapján traumának tekinthető (American Psychiatric Association, 1994), amely a szülők számára az egyik legsúlyosabb stresszkeltő esemény (Kazak, 1998). A DSM-5-ben (American Psychiatric Association, 2013) újdonság azonban, hogy a PTSD már a traumával és stresszorral összefüggő zavarok csoportjába került, amely még kevesebb teret ad annak, hogy a testi betegségek beleférhessenek a trauma definíciójába. A traumatizálódással oly gyakran együttjáró szomatikus egészségproblémákra sem történik semmi utalás a jelenlegi diagnosztikus rendszerben. Ennek ellenére a jelen tanulmány a daganatos betegséget traumának tekinti és egyben a növekedésre való lehetőségként tárgyalja.

Összefoglalva, a gyermekkori daganatos betegséget túlélt fiatal felnőttek és korábban daganatos betegséggel diagnosztizált gyermekek szüleinek vizsgálata a poszttraumás növekedés tekintetében még gyermekcipőben jár, ennek megfelelóen az eddigi eredmények inkonzisztens képet mutatnak, s a poszttraumás növekedés magyarázó változóinak modellbe foglalása is várat magára. Megállapítható ugyanakkor, hogy a poszttraumás növekedés kialakulásában szerepe van egyénen belüli (demográfiai tényezők: nem, életkor, családi állapot, stb.; a fenyegetettség észlelésének mértéke, megküzdési kapacitás, ruminációs folyamatok), szociális (társas támogatottság mértéke) és a traumatikus stresszorral összefüggő (diagnózis óta eltelt idő, betegség szubjektív értékelése, stb.) tényezőknek (Zsigmond és mtsai, 2017) is. Mindezen változók komplex kapcsolatrendszerben hatással lehetnek a poszttraumás növekedés, de a poszttraumás stressztünetek kialakulására és fennmaradására is. Magyar mintán eddig még nem született átfogó vizsgálat ebben a betegpopulációban - a tanulmány ezt a hiányt igyekszik pótolni, s leíró képet adni arról, hogy a PTN milyen formában je- 
lenik meg, s magyarázó változói miként alakulnak a gyermekkori daganatos betegségből gyógyult fiatal felnőtteknél és gyermekkori daganatos betegségen átesett gyermekek szüleiknél. A vizsgálatok ezen iránya a pszichológiai intervenciók tervezése szempontjából nagyon fontos, különös tekintettel a betegség utáni rehabilitáció témakörére - mind a betegségen átesett személy, mind pedig a családi funkcionálás tekintetében.

\section{Módszer}

\subsection{Vizsgálati személyek és eljárás}

A vizsgálatban való részvételre olyan fiatal felnőtteket (18-35 év között) kértünk fel, akik gyermekkori daganatos betegségen estek át, s remisszióban vannak. Emellett daganatos betegségen átesett gyermekek szüleit is vizsgáltuk életkori megkötés nélkül. A kutatásban való részvételre nem egészségügyi szervezeteken, hanem daganatos betegségen átesett gyermekekkel és szüleikkel kapcsolatban lévő alapítványokon, szervezeteken keresztül kértük fel vizsgálati személyeinket. Olyan szervezetekhez juttattuk el a kérdőívcsomagok elérhetőségét, akik gyermekkori daganatos betegséget túlélő fiatal felnőttekkel és szüleikkel vannak kapcsolatban. A szervezetek juttatták el online kérdőívcsomagunkat az érintettekhez, így a kitöltés anonim és önkéntes módon zajlott, a résztvevők elérhetőségeit és személyazonosságát mi nem ismertük. A résztvevők a vizsgálatot bármikor indoklás nélkül megszakíthatták, vagy megtagadhatták a kérdések megválaszolását, szakember elérhetósége is meg volt adva a tájékoztató és beleegyező nyilatkozat során, amennyiben bárminemú kérdés merülne fel. A vizsgálatban résztvevő fiatal felnőtteket és szülőket egyrészt az anonimitás miatt nem tudtuk párosítani, másrészt jelentősen több szülő is töltötte ki a kérdőíveket, így nem összetartozó mintákat vizsgáltunk. A szülói minta eredetileg 202 fót tartalmazott, de a hiányos kitöltések kizárása után 112 fő adatait elemeztük. A fiatal felnőttek mintája eredetileg 100 fős volt, de a nagymértékben hiányos kitöltések kiszelektálása után 53 fó adatait tudtuk elemezni. A vizsgálat az ELTE-PPK Kutatásetikai bizottságának engedélyével zajlott. Az engedély kódja: ELTE PPK kutatásetikai kérelem_2014/10.

Összesen 53 gyermekkori daganatos betegségból gyógyult fiatal felnőtt szerepel a mintánkban, akik átlagosan 27,5 (SD = 5,4) évesek, 17 férfi és 36 nő. A fiatal felnőttek 88,7 \%-a végzett el középiskolát, és több mint fele aktívan dolgozik. 62,3\%-uk anyagi helyzete átlagos, s ugyanennyien élnek párkapcsolatban. A fiatal felnőtt vizsgálati személyek közül 17 leukémián (ALL, AML, CML), 14 limfómán (HL, NHL, BL), 4 osteosarcomán, 2 neuroblastomán, 2 petefészek tumoron, a fennmaradó 14 fő pedig egyéb különböző tumoros megbetegedésen esett át. A vizsgálati személyek közül 20-an 
számoltak be hosszantartó következményekről (pl.: látászavarok, menstruációs problémák, súlyproblémák, bénulás). A fiatal felnőttek diagnóziskori életkora átlagosan 10,77 (SD = 5,76) év volt, a diagnózis óta átlagosan $16,5(\mathrm{SD}=5,6)$ év telt el.

A daganatos betegségen átesett gyermekek szüleinek átlagéletkora 44,9 $(\mathrm{SD}=6,7)$ év, 9 férfi és 103 nő. A szülők 86,6\%-a középfokú iskolai végzettséggel bír, s 75\%-uk dolgozik aktívan, anyagi helyzete 91,2\%-uknak átlagos vagy jobb. A szülők több mint 90\%-a párkapcsolatban él. Gyermekük életkora a diagnóziskor átlagosan 7,32 (SD = 4,44) év volt, a diagnózis óta átlagosan 8,1 (SD = 4,72) év telt el. A demográfiai és betegséggel kapcsolatos változókat az 1-2. táblázatban foglaltuk össze.

1. táblázat. Demográfiai és betegséggel kapcsolatos változók összefoglaló táblázata a gyógyult fiatal felnőttek mintáján

\begin{tabular}{|c|c|c|c|}
\hline \multicolumn{4}{|c|}{ GYÓGYULT FIATAL FELNÓTTEK $(n=53)$} \\
\hline Életkor (átlag, szórás) & $27,5(4,7)$ & \multicolumn{2}{|l|}{ Családi állapot (n,\%) } \\
\hline \multicolumn{2}{|l|}{$\operatorname{Nem}(n, \%)$} & Egyedülálló & $20(37,7)$ \\
\hline Férfi & $17(32,1)$ & Párkapcsolat/házasság & $33(62,3)$ \\
\hline Nő & $36(67,9)$ & Elvált & $0(0)$ \\
\hline \multicolumn{2}{|l|}{ Iskolai végzettség $(\mathrm{n}, \%)$} & Özvegy & $0(0)$ \\
\hline Kevesebb, mint 8 általános & $0(0)$ & \multicolumn{2}{|l|}{ Betegséggel kapcsolatos változók } \\
\hline 8 általános & $2(3,8)$ & \multicolumn{2}{|l|}{ Diagnózis kockázata (n,\%) } \\
\hline Szakmunkásképző & $4(7,5)$ & Kis méretú tumor, nem terjedt & $13(24,5)$ \\
\hline Érettségi & $29(54,7)$ & $\begin{array}{l}\text { Kissé nagyobb méretú tumor, } \\
\text { csak közeli nyirokcsomókba terjedt }\end{array}$ & $14(26,4)$ \\
\hline Egyetemi diploma & $18(34)$ & $\begin{array}{l}\text { Nagyobb tumor, s távolabbi } \\
\text { nyirokcsomókba is terjedt }\end{array}$ & $8(15,1)$ \\
\hline \multicolumn{2}{|l|}{ Munkaerópiaci státusz (n,\%) } & $\begin{array}{l}\text { Nagyméretú tumor, távoli } \\
\text { szervekbe is átterjedt }\end{array}$ & $0(0)$ \\
\hline Diák & $15(28,3)$ & Nincs információ & $18(34)$ \\
\hline Aktív, foóllású & $30(56,6)$ & $\begin{array}{l}\text { Diagnóziskori életkor (év) } \\
\text { (átlag, SD) }\end{array}$ & $\begin{array}{l}10,77 \\
(5,76)\end{array}$ \\
\hline Háztartásbeli & $3(5,7)$ & $\begin{array}{l}\text { Diagnózis óta eltelt idő (év) } \\
\text { (átlag, SD) }\end{array}$ & $\begin{array}{c}16,51 \\
(5,6)\end{array}$ \\
\hline Munkanélküli & $5(9,4)$ & \multicolumn{2}{|l|}{ Kezelések } \\
\hline Nyugdíjas & $0(0)$ & Kemoterápia (n, \%) & $47(88,7)$ \\
\hline \multicolumn{2}{|l|}{ Anyagi helyzet (n,\%) } & Sugárterápia (n, \%) & $25(47,2)$ \\
\hline Átlagosnál rosszabb & $6(11,3)$ & Műtét (n, \%) & $25(47,2)$ \\
\hline Átlagos & $33(62,3)$ & Transzplantáció (n, \%) & $4(7,5)$ \\
\hline Átlagosnál jobb & $14(26,4)$ & & \\
\hline
\end{tabular}


2. táblázat. Demográfiai és betegséggel kapcsolatos változók összefoglaló táblázata a daganatos betegségen átesett gyermekek szüleinek mintáján

\begin{tabular}{|c|c|c|c|}
\hline \multicolumn{4}{|c|}{ SZÜLŐK $(n=112)$} \\
\hline Életkor (átlag, szórás) & $44,9(6,7)$ & \multicolumn{2}{|l|}{ Családi állapot $(\mathrm{n}, \%)$} \\
\hline \multicolumn{2}{|l|}{$\operatorname{Nem}(n, \%)$} & Egyedülálló & $4(3,6)$ \\
\hline Férfi & $9(8)$ & Párkapcsolat/házasság & $102(91,1)$ \\
\hline Nő & $103(92)$ & Elvált & $4(3,6)$ \\
\hline \multicolumn{2}{|l|}{ Iskolai végzettség $(\mathrm{n}, \%)$} & Özvegy & $2(1,8)$ \\
\hline Kevesebb, mint 8 általános & $1(0,9)$ & \multicolumn{2}{|c|}{ Gyermek betegségével kapcsolatos változók } \\
\hline 8 általános & $2(1,8)$ & \multicolumn{2}{|l|}{ Diagnózis kockázata (n,\%) } \\
\hline Szakmunkásképző & $12(10,7)$ & Kis méretú tumor, nem terjedt & $24(21,4)$ \\
\hline Érettségi & $42(37,5)$ & $\begin{array}{l}\text { Kissé nagyobb méretú tumor, csak } \\
\text { közeli nyirokcsomókba terjedt }\end{array}$ & $25(22,3)$ \\
\hline Egyetemi diploma & $55(49,1)$ & $\begin{array}{l}\text { Nagyobb tumor, s távolabbi } \\
\text { nyirokcsomókba is terjedt }\end{array}$ & $15(13,4)$ \\
\hline \multicolumn{2}{|l|}{ Munkaerópiaci státusz (n,\%) } & $\begin{array}{l}\text { Nagyméretú tumor, távoli } \\
\text { szervekbe is átterjedt }\end{array}$ & $3(2,7)$ \\
\hline Diák & $0(0)$ & Nincs információ & $15(13,4)$ \\
\hline Aktív, főállású & $84(75)$ & $\begin{array}{l}\text { Diagnóziskori életkor (év) } \\
\text { (átlag, SD) }\end{array}$ & $\begin{array}{c}7,32 \\
(4,44)\end{array}$ \\
\hline Háztartásbeli & $21(18,8)$ & $\begin{array}{l}\text { Diagnózis óta eltelt idő (év) } \\
\text { (átlag, SD) }\end{array}$ & $8,1(4,72)$ \\
\hline Munkanélküli & $2(1,8)$ & \multicolumn{2}{|l|}{ Kezelések } \\
\hline Nyugdíjas & $5(4,5)$ & Kemoterápia (n, \%) & $105(93,8)$ \\
\hline \multicolumn{2}{|l|}{ Anyagi helyzet $(n, \%)$} & Sugárterápia (n, \%) & $21(18,8)$ \\
\hline Átlagosnál rosszabb & $11(9,8)$ & Mútét (n, \%) & $50(44,6)$ \\
\hline Átlagos & $70(62,5)$ & Transzplantáció (n, \%) & $17(15,2)$ \\
\hline Átlagosnál jobb & $31(27,7)$ & & \\
\hline
\end{tabular}

\subsection{Mérőeszközök}

Demográfiai adatok. A demográfiai adatok a vizsgálati személy nemét, életkorát, legmagasabb iskolai végzettségét, családi állapotát, munkaerópiaci státuszát és anyagi helyzetét tartalmazta.

Betegségváltozók. A betegséggel kapcsolatos változók körében felmértük a diagnózist, a diagnózis kockázatát, a diagnózis időpontját, a diagnózis óta eltelt időt, a személy életkorát a diagnózis idején. Feltártuk a kezelés típusát 
és jellemzőit, az esetleges mútét vagy transzplantáció meglétét. Rákérdeztünk a visszaesésre, és a betegség és a kezelés hosszú távú következményeire is.

Poszttraumás Növekedés Kérdőív. A poszttraumás növekedés vizsgálatára a Tedeschi és Calhoun $(1996,2004)$ által kifejlesztett Posttraumatic Growth Inventory (PTGI) magyar nyelvú, validált változatát használtuk (Kovács, Balog, \& Preisz, 2012), amely a PTN öt dimenzióját méri 6-fokú Likerttípusú skálán a Nem tapasztaltam ezt a változást az említett krízis következményeként (0) és a Nagyon nagy mértékben tapasztaltam ezt a változást az említett krízis következményeként (5) végpontok között. A kérdőív 21 tétele a PTN 5 dimenziójának megfelelően 5 alskálát alkot: az élet fokozottabb értékelése, fejlődő interperszonális kapcsolatok, a személyes erő fokozottabb érzése, az új életlehetőségek felismerése, a spirituális és vallási növekedés. A skálaképzés a tételek összeadásával és az átlag kiszámításával történik. A skálapontszám kiszámítása mellett kategóriaképzésre is van lehetőség: 1 pont felett enyhe, 3 pont felett közepes és 4 pont felett nagymértékú növekedésről beszélhetünk az egyes dimenziók mentén. A kérdőív magyar nyelvú változata megbízhatónak bizonyult (Kovács és mtsai, 2012). Jelen vizsgálat során is erős belső konzisztenciával bírt a méróeszköz: a Cronbach-a értéke 0,93 volt. Az alskálák megbízhatósága is megfelelő volt, a Cronbach-a értékei 0,74-0,87 között alakultak, kivéve a spiritualitás alskálát, amely elmaradt a várt kritériumtól (Cronbach- $\mathrm{a}=0,57$ ).

Társas Támogatottság Kérdőív. A társas támogatás mértékét a Caldwell, Pearson és Chin (1987) által kifejlesztett Support Dimension Scale rövidített, magyar változatával (Tandari-Kovács, 2010) vizsgáltuk, amely a társas támogatás észlelt szintjét méri (Kopp, Skrabski, \& Neukem, 1992), 4-fokú Likert-típusú skálán az Egyáltalán nem számíthatott az alábbiak segitségére (0) és a Nagyon számíthatott az alábbiak segítségére (4) végpontok között. Vizsgálatunk során a kérdőívet két verzióban használtuk mind a daganatos betegséget túlélt fiatal felnőttek, mind a szülők esetében - az egyik a betegség idejére, a másik az általános társas támogatásra vonatkozott. A fiatal felnőtteknél a betegség idejére vonatkozó kérdőívben a szülőktől, iskolatárstól, szomszéd tól, baráttól, rokonoktól, segítő foglalkozásúaktól, egyházi csoporttól, segító szervezettől és sorstársaktól megélt társas támogatásra kérdeztünk rá. Az általános társas támogatás tekintetében ez kiegészült a munkatárssal, gyermekkel és élettárssal vagy házastárssal, azonban a sorstársra vonatkozó kérdés nem szerepelt benne. A szülők esetében a betegség idejére vonatkozó és az általános társas támogatással kapcsolatos kérdések megegyeztek. A társas támogatás mértékét Caldwell és munkatársai (1987) nyomán az összpontszám alapján határoztuk meg. A magasabb pontszám nagyobb mértékú társas támogatottságot jelzett. A kérdőív megbízhatósága korábbi vizsgálatok alapján elfogadható (Nyulászi \& Rigó, 2014). Jelen vizs- 
gálatunkban a betegség idejére vonatkozó társas támogatás skála esetében a Cronbach-a a szülő́k mintáján 0,65, míg a fiatal felnőttek mintáján 0,70 lett. Az általános társas támogatás Cronbach-a mutatója a szülők mintáján 0,62, míg a fiatal felnőtteknél 0,60 lett. Mivel a kérdőív jellegéből fakadóan nem várjuk a tételek szoros összefüggését, így ezeket elfogadhatónak ítéltük.

Események Hatása Kérdôív (IES-R). A poszttraumás stressztünetek vizsgálatára a Horowitz Wilner és Alvarez (1979) által kifejlesztett Impact of Events Scale tovább fejlesztett, magyar változatát használtuk (PerczelForintos, Ajtay, Barna, Kiss, \& Komlósi, 2012), amely a traumatikus esemény hatására megélt szubjektív distressz tünetek szintjét méri 5-fokú Likert-típusú skálán az Egyáltalán nem voltak jellemzőek (0) és a Mindig jellemzőek voltak (4) végpontok között. Jelen kérdőív az eredeti két területet méró (elkerülés, emlékbetörés) kérdéssor hyperarousal tünetekkel kiegészített változata (Weiss \& Marmar, 1997), amely így 7 tétellel bővült. A kitöltőknek a betegség idejére vonatkozóan kellett meghatározniuk, hogy az egyes állítások mennyire voltak jellemzőek rájuk. A magasabb pontszám, magasabb szubjektív distressz szintet jelent egy negatív életesemény kapcsán. A három alskála belső megbízhatóságának mutatói megfelelőnek bizonyultak, a Cronbach-a értéke a hyperarousal tekintetében 0,79, az emlékbetörés alskála esetében 0,85 , míg az elkerülés esetében 0,66 volt. A teljes kérdőív megbízhatósági mutatója megfelelő (Cronbach-a =0,87).

Pozitív Érzelmekre Adott Válaszok Kérdőív. Az érzelemszabályozás - különös tekintettel a rumináció - mérésére a Feldman és munkatársai (2008) által kifejlesztett Responses to Positive Affect Questionnaire magyar változatát használtuk, amelynek magyar nyelvre adaptálását Kökönyei Gyöngyi és munkacsoportja végzi. Mivel a kérdőív hazai validálása még zajlik, az eredeti háromfaktoros struktúrát használtuk. A kérdőív három kognitív, válaszfókuszú, érzelemszabályozó stratégiát mér. Azt méri fel, hogy a személy a pozitív érzelmi állapotaira (pl.: amikor boldog) milyen gondolatokkal reagál. Az "Amikor boldog vagyok, akkor” kezdetú kérdésre válaszolva kell eldöntenie a kitöltőnek, hogy mennyire jellemző rá általában az adott gondolat [a 4-fokú Likert-típusú skálán a válaszlehetőségek végpontjai: Szinte soha (0) és Szinte mindig (3)]. Az összes kérdésnél abból kell kiindulnia a kitöltónek, hogy amikor jól érzi magát, boldog, akkor általában hogyan gondolkodik. Két pozitív stratégia (érzelemfókuszú és énfókuszú rumináció) és egy negatív (pozitív érzelmekre vonatkozó elfojtás) mérhető a 17 tételes kérdőívvel. Az érzelemfókuszú stratégiára példa item: Amikor jól érzi magát (boldog), milyen gyakran gondolja, hogy „bármire képes vagyok"? Az énfókuszú stratégiára példa item: Amikor jól érzi magát (boldog), milyen gyakran gondolja, hogy "kész vagyok bármit megtenni"? A pozitív érzelmekre vonatkozó elfojtásra példa item: Amikor jól érzi magát (boldog), milyen gyakran gondolja azt, hogy „ez túl szép ahhoz, hogy igaz legyen"? Az eredeti kérdóívvel folytatott 
validálási vizsgálat alapján a mérőeszköz belső megbízhatósága megfelelő (Feldman és mtsai, 2008). A magyar nyelvú változat jelen vizsgálatunk során is megbízhatónak bizonyult: a Cronbach-a értékei 0,74 és 0,82 között mozogtak.

WHO Jóllét Kérdőív. A daganatos betegségen átesett fiatal felnőttek és szüleinek jelenlegi (elmúlt két hétre vonatkozó) pszichológiai jóllétének vizsgálatára a WHO Jóllét Kérdőívet alkalmaztuk. Az eredeti 1982-ben kidolgozott 22 tételes Jóllét Indexet Bech, Gudex és Johansen (1996) alakította 5 tétel rövidségúre, hogy az egészségügyben is könnyen használható legyen. A WHO Jól-lét Kérdőív 5 tételes magyar változatát 2006-ban validálták, amely alapján a kérdőív belső konzisztenciája megfelelő (Susánszky, Konkolÿ Thege, Stauder, \& Kopp, 2006). Az 5 tételt 4-fokozatú Likert-típusú skálán az Egyáltalán nem jellemző (0) és a Teljesen jellemző (3) végpontok között kell értékelnie a kitöltőnek. A magasabb pontszám jobb általános közérzetet jelez. Jelen vizsgálatunkkor a kérdőív megbízhatósága ugyancsak kiváló lett (Cronbach-a = 0,86).

\subsection{Statisztikai eljárások}

A kérdőívcsomagok megosztását és kitöltését, valamint az adatok letöltését a LimeSurvey online alkalmazás felületén végeztük el. Az adatok rendszerezése és a statisztikai eljárások elvégzése pedig az IBM SPSS programcsomag 22-es verziója segítségével valósult meg. Leíró statisztikai elemzéseket (átlag, SD, gyakoriság és százalékos megoszlás) végeztünk a minta jellemzőinek leírására. Pearson-féle korrelációs eljárást alkalmaztunk a vizsgált változók együttjárásának vizsgálatára külön-külön a két csoportban. A poszttraumás növekedést meghatározó változók komplex vizsgálatára többváltozós lineáris regresszió elemzést végeztünk (stepwise regression, backward elimination) mind a két csoportban, valamint a poszttraumás növekedés különböző dimenzióinak mentén is.

\section{Eredmények}

3.1. A poszttraumás növekedés és a vele kapcsolatos változók jellemzői, korrelációs vizsgálatok

A gyógyult fiatal felnőttek 97,9\%-a átélt legalább enyhe mértékú növekedést (PTN átlagolt összpontszáma 1 pont felett), 66,7\%-uk pedig legalább közepes mértékben tapasztalta a változást (PTN átlagolt összpontszám 3 pont felett), 17\%-uk pedig nagy mértékú növekedésről számolt be (PTN 
átlagolt összpontszáma 4 felett). A szülők 93\%-a számolt be legalább kis mértékú növekedésről, míg 62\%-uk legalább közepes mértékú növekedésről, 23\%-uk pedig nagy mértékú növekedésről. A PTN átlagolt összpontszáma mind a két csoportban közepes mértékú növekedésre utalt. A PTN megjelenési szintjének (enyhe, közepes, nagy, stb.) gyakorisági eloszlásait az 1-2. ábrán mutatjuk be.

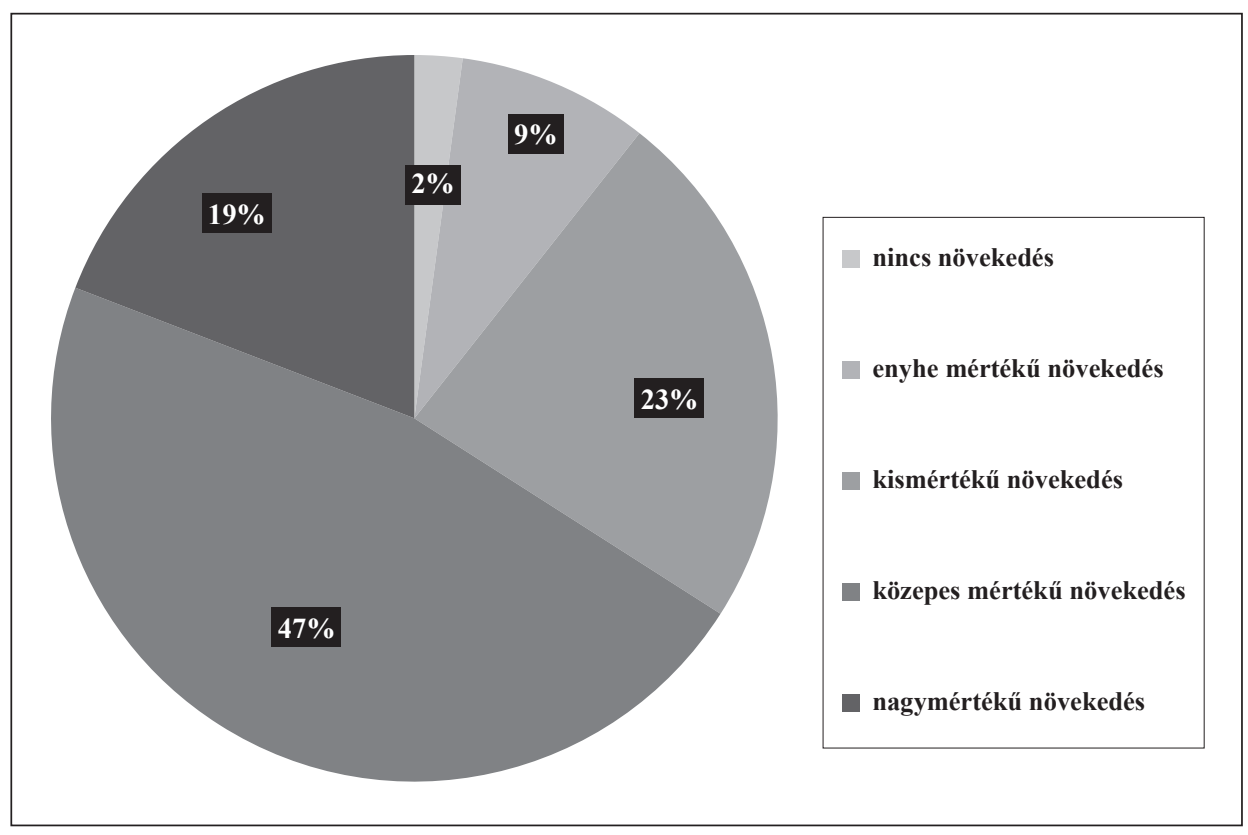

1. ábra. A poszttraumás növekedés megjelenési szintjeinek előfordulási gyakorisága a gyógyult fiatal felnőttek mintáján

A faktorok közül a legmagasabb pontszámot mind a két csoportban az Élet értékelése területén érték el a vizsgálati személyek. A fiatal felnőtteknél ezt követte a Kapcsolatok, a Személyes erő, az Új életlehetőségek közepes mértékú növekedést mutatva, míg a Spirituális változás jóval alacsonyabb értékkel jelent meg. A szülők mintáján az Élet értékelését a Személyes erő, majd a Kapcsolatok követte közepes mértékú növekedést mutatva, majd az Új életlehetőségek és a Spirituális változás következett alacsonyabb mértékú növekedéssel. A Poszttraumás Növekedés Kérdőíven elért átlagokat a 3. táblázat foglalja össze. 


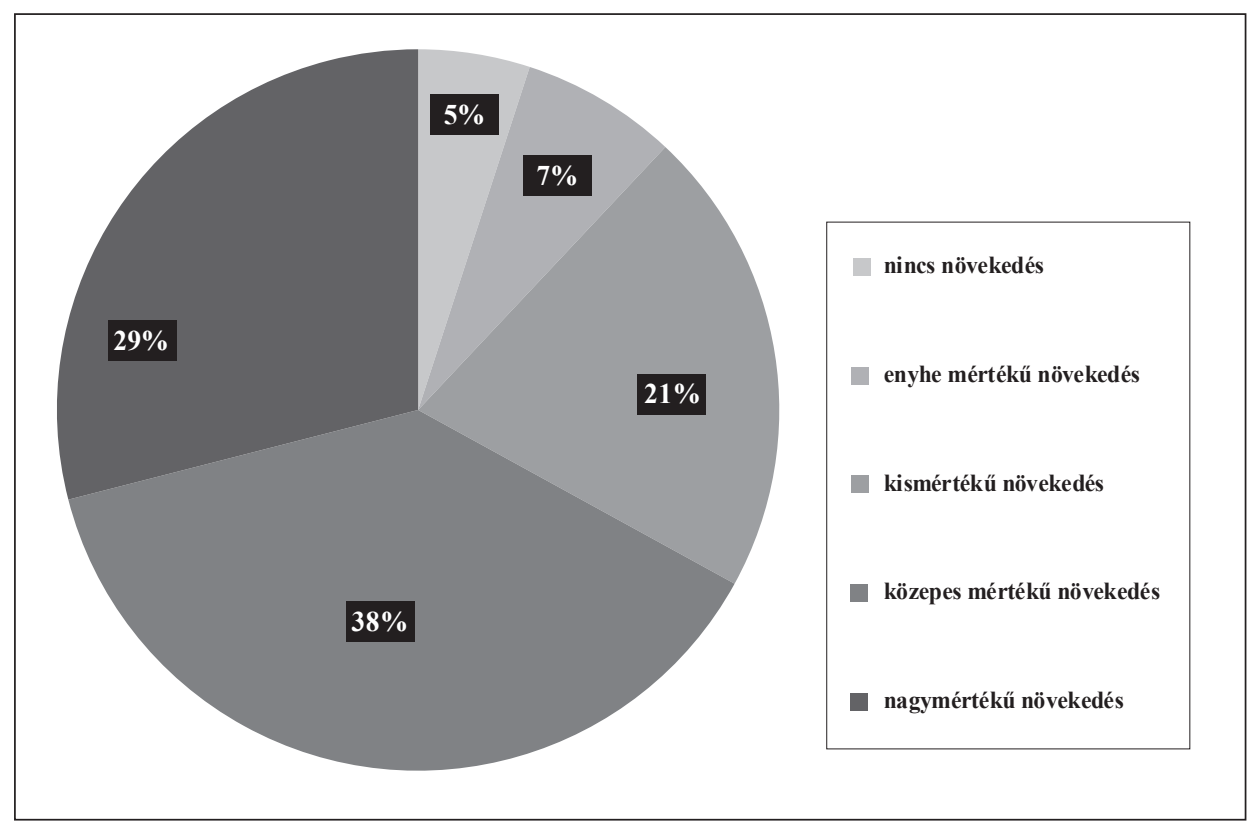

2. ábra. A poszttraumás növekedés megjelenési szintjeinek előfordulási gyakorisága a szülők mintáján

3. táblázat. A poszttraumás növekedés összpontszámának és faktorainak megjelenése a gyógyult fiatal felnőttek és a szülők csoportjában

\begin{tabular}{|c|c|c|c|c|c|c|c|c|}
\hline \multirow{3}{*}{$\begin{array}{l}\text { Poszttraumás } \\
\text { Növekedés } \\
\text { Kérdőív }\end{array}$} & \multicolumn{4}{|c|}{$\begin{array}{l}\text { Gyógyult fiatal felnóttek } \\
\qquad(n=53)\end{array}$} & \multicolumn{4}{|c|}{$\begin{array}{l}\text { Szülők } \\
(n=112)\end{array}$} \\
\hline & \multirow[t]{2}{*}{ átlag } & \multirow[t]{2}{*}{ SD } & \multicolumn{2}{|c|}{$95 \% \mathrm{CI}$} & \multirow[t]{2}{*}{ átlag } & \multirow[t]{2}{*}{ SD } & \multicolumn{2}{|c|}{$95 \% \mathrm{CI}$} \\
\hline & & & $\begin{array}{l}\text { Alsó } \\
\text { határ }\end{array}$ & $\begin{array}{l}\text { Felső } \\
\text { határ }\end{array}$ & & & $\begin{array}{l}\text { Alsó } \\
\text { határ }\end{array}$ & $\begin{array}{l}\text { Felső } \\
\text { határ }\end{array}$ \\
\hline PTN összpontszám & 3,18 & 0,97 & 2,88 & 3,44 & 3,15 & 0,98 & 2,94 & 3,33 \\
\hline Élet értékelése & 3,70 & 1,17 & 3,32 & 4,02 & 4,03 & 0,95 & 3,85 & 4,21 \\
\hline Kapcsolatok & 3,29 & 1,15 & 2,94 & 3,60 & 3,22 & 1,09 & 2,99 & 3,42 \\
\hline Személyes erő & 3,29 & 1,16 & 2,93 & 3,62 & 3,28 & 1,19 & 3,04 & 3,49 \\
\hline Új életlehetőségek & 3,17 & 1,08 & 2,85 & 3,45 & 2,83 & 1,19 & 2,56 & 3,07 \\
\hline Spirituális változás & 1,79 & 1,59 & 1,32 & 2,25 & 2,13 & 1,49 & 1,85 & 2,42 \\
\hline
\end{tabular}

Megjegyzés: 95\% CI = 95\%-os megbízhatósági intervallum. 
A korrelációs vizsgálatok eredményeinek (4. táblázat) tanulsága szerint a gyógyult fiatal felnőttek csoportjában az érzelemfókuszú rumináció és a pszichológiai jóllét voltak erős, pozitív irányú, szignifikáns kapcsolatban a poszttraumás növekedéssel. A betegség idejére vonatkozó társas támogatás, az általános társas támogatás és az énközpontú rumináció mérsékelt erősségú, pozitív irányú, szignifikáns kapcsolatot mutattak a poszttraumás növekedéssel. A poszttraumás stressztünetek közül egyedül az emlékbetörés korrelált szignifikánsan a PTN-nel, amely összefüggés pozitív irányú és gyenge, a diagnózis óta eltelt idő pedig mérsékelt erősségú, negatív irányú, szignifikáns összefüggést mutatott a PTN-nel.

A szülők mintáján az énközpontú és érzelemfókuszú rumináció, a poszttraumás stressztünetek közül a hyperarousal és a poszttraumás stressztünetek összpontszáma, valamint a pszichológiai jóllét volt mérsékelt erősségú, pozitív irányú, szignifikáns kapcsolatban a PTN-nel. A poszttraumás stressztünetek közül az emlékbetörés, valamint a pozitív érzelmekre vonatkozó elfojtás pozitív irányú, gyenge, szignifikáns, kapcsolatban volt a PTN-nel.

4. táblázat. A poszttraumás növekedéssel kapcsolatban álló változók korrelációs mutatói a gyógyult fiatal felnőttek és a szülők csoportjában

\begin{tabular}{|l|c|c|}
\hline \multicolumn{1}{|c|}{ Változók } & $\begin{array}{c}\text { Gyógyult fiatal } \\
\text { felnoottek }(\boldsymbol{n}=\mathbf{5 3})\end{array}$ & $\begin{array}{c}\text { Szülő́k } \\
(\boldsymbol{n}=\mathbf{1 1 2})\end{array}$ \\
\hline Diagnózis óta eltelt idő & $-0,32^{*}$ & 0,03 \\
\hline Betegség idejére vonatkozó társas támogatás & $0,36^{* *}$ & 0,03 \\
\hline Társas támogatás általában & $0,39^{* *}$ & 0,18 \\
\hline Poszttraumás stressztünetek: emlékbetörés & $0,29^{* *}$ & $0,27^{* *}$ \\
\hline Poszttraumás stressztünetek: hyperarousal & 0,21 & $0,32^{* *}$ \\
\hline Poszttraumás stressztünetek: elkerülés & $-0,11$ & 0,19 \\
\hline Poszttraumás stressztünetek: összpontszám & 0,15 & $0,33^{* *}$ \\
\hline Érzelemszabályozás: énközpontú rumináció & $0,39^{* *}$ & $0,42^{* *}$ \\
\hline Érzelemszabályozás: érzelemközpontú rumináció & $0,57^{* *}$ & $0,33^{* *}$ \\
\hline $\begin{array}{l}\text { Érzelemszabályozás: pozitív érzelmekre } \\
\text { vonatkozó elfojtás }\end{array}$ & 0,16 & $0,21^{*}$ \\
\hline Pszichológiai jóllét & $0,51^{* *}$ & $0,31^{* *}$ \\
\hline
\end{tabular}

Megjegyzés: A poszttraumás növekedést a PTN skála átlagolt összpontszámával mértük. Pearson-féle korrelációs együtthatók. ${ }^{*} p<0,05 ;{ }^{* *} p<0,01$. 


\subsection{A poszttraumás növekedés magyarázó változói}

\subsubsection{Gyógyult fiatal felnőttek csoportja}

A poszttraumás növekedést meghatározó változók komplex vizsgálatára többváltozós lineáris regresszió elemzést végeztünk. A kimeneti változó a poszttraumás növekedés átlagolt összpontszáma volt. A magyarázó, bemeneti változók közé szakirodalmi megfontolások és a korrelációs vizsgálatok eredményei alapján a kezdeti modellbe a diagnózis óta eltelt idő, a diagnóziskori életkor, a társas támogatás két formája és az érzelemfókuszú, valamint az énfókuszú rumináció és a pozitív érzelmekre vonatkozó elfojtás, a poszttraumás stressztünetek közül az emlékbetörés és a hyperarousal, valamint a nem és a jóllét kerültek be a gyógyult fiatal felnóttek csoportjában.

A többlépcsős vizsgálat (stepwise regression, backward elimination) után, a végső modellben a pozitív érzelmekre vonatkozó elfojtás, a poszttraumás stressztünetek közül az emlékbetörés, valamint a jóllét maradtak szignifikáns magyarázó változók (5. táblázat). A legnagyobb magyarázó ereje a jóllétnek volt. Az általános társas támogatás esetén csak tendencia szintú volt az összefüggés, de úgy ítéltük meg, hogy egyrészt határértéken mozog, másrészt a modell magyarázó ereje jelentősen csökkent volna a kihagyásával. A vizsgált modell a PTN varianciájának 50,7\%-át magyarázta $\left(\mathrm{R}^{2}=0,507 ; F(4)=10,562 ; p=0,001\right)$. Megállapíthatjuk tehát, hogy az általános társas támogatás magasabb szintje, a pozitív érzelmekre vonatkozó elfojtás és az emlékbetörések fokozottabb jelenléte, valamint a pszichológiai jóllét fokozottabb szubjektív érzésének a szintje nagy hányadát magyarázza a poszttraumás növekedés megemelkedett szintjének.

5. táblázat. Lépésenkénti regressziós vizsgálat végső modellje a gyógyult fiatal felnőttek mintáján a poszttraumás növekedés magyarázó változóira

\begin{tabular}{|l|c|c|c|c|c|}
\hline \multicolumn{1}{|c|}{ Változók } & $\boldsymbol{B}$ & $\begin{array}{c}\text { Sztenderd } \\
\text { hiba }\end{array}$ & $\boldsymbol{\beta}$ & $\boldsymbol{t}$ & $\boldsymbol{p}$ \\
\hline Társas támogatás általában & 0,917 & 0,465 & 0,234 & 1,971 & 0,055 \\
\hline $\begin{array}{l}\text { Pozitív érzelmekre vonatkozó } \\
\text { elfojtás }\end{array}$ & 1,097 & 0,497 & 0,253 & 2,205 & 0,033 \\
\hline $\begin{array}{l}\text { Poszttraumás stressztünetek: } \\
\text { emlékbetörés }\end{array}$ & 1,312 & 0,404 & 0,374 & 3,25 & 0,002 \\
\hline Pszichológiai jóllét & 3,743 & 0,703 & 0,622 & 5,324 & $<0,001$ \\
\hline
\end{tabular}


A PTN faktorai esetében ugyanezen bemeneti változókkal külön regreszsziós számításokat is végeztünk. A PTN összpontszámára vonatkozó modellhez képest az Élet értékelése faktor tekintetében szerepet kapott még a válaszadók neme (nőknél magasabb volt), de a társas támogatásnak nem volt szignifikáns magyarázó ereje. A Kapcsolatok tekintetében a betegség idejére vonatkozó társas támogatás vette át az általános társas támogatás szerepét, s a pozitív érzelmekre vonatkozó elfojtás előrejelző értéke nem jelent meg. A Személyes erő tekintetében csak a pszichológiai jóllétnek volt szerepe. Az Új életlehetőségek esetében a poszttraumás stressztünetek közül az elkerülés és a diagnózis óta eltelt időnek is volt szerepe a PTN összpontszámát magyarázó modell változói mellett, de a kapcsolat iránya negatív volt. A Spiritualitás esetében a pszichológiai jóllét és a pozitív érzelmekre vonatkozó elfojtás kikerültek a modellből. A PTN faktorainak végsó magyarázó modelljeit a 6. táblázatban foglaljuk össze.

6. táblázat. Lépésenkénti regressziós vizsgálatok végső modelljei a PTN faktorainak magyarázó változói tekintetében a gyógyult fiatal felnőttek mintáján

\begin{tabular}{|c|c|c|c|c|c|c|}
\hline \multicolumn{2}{|c|}{ Modellek } & $B$ & $\begin{array}{c}\text { Sztenderd } \\
\text { hiba }\end{array}$ & $\beta$ & $t$ & $p$ \\
\hline \multicolumn{7}{|c|}{ 1. Poszttraumás növekedés: Élet értékelése faktor magyarázó változói } \\
\hline \multirow[t]{4}{*}{$\mathbf{R}^{2}=0,45$} & $\begin{array}{l}\text { Pozitív } \\
\text { érzelmekre } \\
\text { vonatkozó } \\
\text { elfojtás }\end{array}$ & 0,227 & 0,088 & 0,304 & 2,586 & 0,013 \\
\hline & $\begin{array}{l}\text { Poszttraumás } \\
\text { stressztünetek: } \\
\text { emlékbetörés }\end{array}$ & 0,232 & 0,071 & 0,384 & 3,262 & 0,002 \\
\hline & $\begin{array}{l}\text { Pszichológiai } \\
\text { jóllét }\end{array}$ & 0,521 & 0,124 & 0,501 & 4,195 & $<0,001$ \\
\hline & Nem & 2,126 & 0,879 & 0,28 & 2,418 & 0,020 \\
\hline \multicolumn{7}{|c|}{ 2. Poszttraumás növekedés: Kapcsolatok faktor magyarázó változói } \\
\hline \multirow[t]{3}{*}{$R^{2}=0,431$} & $\begin{array}{l}\text { Betegség idejére } \\
\text { vonatkozó társas } \\
\text { támogatás }\end{array}$ & 0,623 & 0,231 & 0,327 & 2,696 & 0,010 \\
\hline & $\begin{array}{l}\text { Poszttraumás } \\
\text { stressztünetek: } \\
\text { emlékbetörés }\end{array}$ & 0,478 & 0,17 & 0,342 & 2,814 & 0,007 \\
\hline & $\begin{array}{l}\text { Pszichológiai } \\
\text { jóllét }\end{array}$ & 0,988 & 0,289 & 0,412 & 3,414 & 0,001 \\
\hline
\end{tabular}


6. táblázat folytatása

\begin{tabular}{|c|c|c|c|c|c|c|}
\hline \multicolumn{2}{|c|}{ Modellek } & $B$ & $\begin{array}{l}\text { Sztenderd } \\
\text { hiba }\end{array}$ & $\beta$ & $t$ & $p$ \\
\hline \multicolumn{7}{|c|}{ 3. Poszttraumás növekedés: Személyes eró faktor magyarázó változója } \\
\hline$R^{2}=0,393$ & $\begin{array}{l}\text { Pszichológiai } \\
\text { jóllét }\end{array}$ & 0,876 & 0,163 & 0,627 & 5,336 & $<0,001$ \\
\hline \multicolumn{7}{|c|}{ 4. Poszttraumás növekedés: Új életlehetőségek faktor magyarázó változói } \\
\hline \multirow[t]{5}{*}{$R^{2}=0,439$} & $\begin{array}{l}\text { Pozitív } \\
\text { érzelmekre } \\
\text { vonatkozó } \\
\text { elfojtás }\end{array}$ & 0,334 & 0,138 & 0,292 & 2,412 & 0,021 \\
\hline & $\begin{array}{l}\text { Poszttraumás } \\
\text { stressztünetek: } \\
\text { emlékbetörés }\end{array}$ & 0,336 & 0,126 & 0,363 & 2,667 & 0,011 \\
\hline & $\begin{array}{l}\text { Poszttraumás } \\
\text { stressztünetek: } \\
\text { elkerülés }\end{array}$ & $-0,284$ & 0,138 & $-0,277$ & $-2,058$ & 0,046 \\
\hline & $\begin{array}{l}\text { Pszichológiai } \\
\text { jóllét }\end{array}$ & 0,656 & 0,201 & 0,412 & 3,27 & 0,002 \\
\hline & $\begin{array}{l}\text { Diagnózis óta } \\
\text { eltelt idő }\end{array}$ & $-0,248$ & 0,119 & $-0,260$ & $-2,078$ & 0,044 \\
\hline \multicolumn{7}{|c|}{ 5. Poszttraumás növekedés: Spirituális változás faktor magyarázó változói } \\
\hline \multirow[t]{3}{*}{$R^{2}=0,347$} & $\begin{array}{l}\text { Társas támogatás } \\
\text { általában }\end{array}$ & 0,209 & 0,078 & 0,338 & 2,678 & 0,011 \\
\hline & $\begin{array}{l}\text { Poszttraumás } \\
\text { stressztünetek: } \\
\text { hyperarousal }\end{array}$ & 0,225 & 0,108 & 0,294 & 2,082 & 0,044 \\
\hline & $\begin{array}{l}\text { Poszttraumás } \\
\text { stressztünetek: } \\
\text { elkerülés }\end{array}$ & $-0,302$ & 0,087 & $-0,495$ & $-3,473$ & 0,001 \\
\hline
\end{tabular}

\subsubsection{Szülők csoportja}

A szülők mintáján elvégzett többváltozós lineáris regresszió elemzés kimeneti változója ezúttal is a poszttraumás növekedés átlagolt összpontszáma volt, míg a bemeneti változói között szerepelt a gyermek diagnózisának súlyossága, a poszttraumás stressztünetek közül az elkerülés, a hyperarousal és az emlékbetörés, az érzelemfókuszú és énfókuszú rumináció és a pozitív 
érzelmekre vonatkozó elfojtás, a betegség idejére vonatkozó és az általános társas támogatás és a pszichológiai jóllét. A többlépcsős vizsgálat (stepwise regression, backward elimination) után, a végső modellben az énfókuszú pozitív rumináció, a poszttraumás stressztünetek közül a hyperarousal és a jóllét maradtak meg szignifikáns magyarázó változóknak. A vizsgált modell a PTN varianciájának 26,5\%-át magyarázta $\left(R^{2}=0,265 ; F(3)=6,729 ; p=\right.$ $0,001)$. Az eredményeket a 7. táblázat foglalja össze. Megállapíthatjuk tehát, hogy a hyperarousal tünetek fokozottabb jelenléte, az énfókuszú ruminációs érzelemszabályozási folyamatok hangsúlyosabb használata, valamint a jóllét fokozottabb szubjektív érzésének a szintje magyarázza a poszttraumás növekedés megemelkedett szintjének egynegyedét.

7. táblázat. Lépésenkénti regressziós vizsgálat végső modellje a szülők mintáján

\begin{tabular}{|l|c|c|c|c|c|}
\hline \multicolumn{1}{|c|}{ Változók } & $\boldsymbol{B}$ & $\begin{array}{c}\text { Sztenderd } \\
\text { hiba }\end{array}$ & $\boldsymbol{\beta}$ & $\boldsymbol{t}$ & $\boldsymbol{p}$ \\
\hline $\begin{array}{l}\text { Poszttraumás stressztünetek: } \\
\text { hyperarousal }\end{array}$ & 2,064 & 0,636 & 0,396 & 3,244 & 0,002 \\
\hline Én-fókuszú rumináció & 2,903 & 1,175 & 0,31 & 2,47 & 0,017 \\
\hline Pszichológiai jóllét & 1,669 & 0,78 & 0,275 & 2,139 & 0,037 \\
\hline
\end{tabular}

A PTN faktorai esetében ugyanezen bemeneti változókkal külön regressziós számításokat is végeztünk. A PTN átlagolt összpontszámára vonatkozó modellhez képest az Élet értékelése faktor szignifikáns magyarázó változói közé bekerült még a pozitív érzelmekre vonatkozó elfojtás, de nem kapott szerepet semmilyen poszttraumás stressztünet. A Kapcsolatok faktor esetében az eredeti modellhez képest a pszichológiai jóllét nem játszott szerepet. A Személyes eró szempontjából csak az énfókuszú ruminációnak volt szerepe. Az Új életlehetóségek terén viszont az énfókuszú rumináció kikerült, s csak a hyperarousalnak és a pszichológiai jóllétnek volt szerepe. A Spiritualitás terén a betegség idejére vonatkozó társas támogatásnak negatív, míg az általános társas támogatásnak pozitív hatása volt, emellett a hyperarousal bizonyult kisebb hatású magyarázó változónak. A PTN faktorainak végső magyarázó modelljeit a 8. táblázat foglalja össze. 
8. táblázat. Lépésenkénti regressziós vizsgálatok végső modelljei a PTN faktorainak tekintetében a szülők mintáján

\begin{tabular}{|c|c|c|c|c|c|c|}
\hline & Modellek & $B$ & $\begin{array}{l}\text { Sztenderd } \\
\quad \text { hiba }\end{array}$ & $\beta$ & $t$ & $p$ \\
\hline \multicolumn{7}{|c|}{ 1. Poszttraumás növekedés: Élet értékelése faktor magyarázó változói } \\
\hline \multirow[t]{3}{*}{$R^{2}=0,293$} & Énfókuszú rumináció & 0,412 & 0,151 & 0,341 & 2,721 & 0,009 \\
\hline & $\begin{array}{l}\text { Pozitív érzelmekre } \\
\text { vonatkozó elfojtás }\end{array}$ & 0,294 & 0,086 & 0,409 & 3,407 & 0,001 \\
\hline & Jóllét & 0,226 & 0,097 & 0,289 & 2,336 & 0,023 \\
\hline
\end{tabular}

2. Poszttraumás növekedés: Kapcsolatok faktor magyarázó változói

\begin{tabular}{|l|l|c|c|c|c|c|}
\hline $\mathbf{R}^{2}=\mathbf{0 , 1 6 1}$ & $\begin{array}{l}\text { Poszttraumás } \\
\text { stressztünetek: } \\
\text { hyperarousal }\end{array}$ & 0,534 & 0,241 & 0,277 & 2,216 & 0,031 \\
\cline { 2 - 7 } & Énfókuszú rumináció & 1,266 & 0,433 & 0,365 & 2,921 & 0,005 \\
\hline
\end{tabular}

3. Poszttraumás növekedés: Személyes eró faktor magyarázó változója

\begin{tabular}{|l|l|l|l|l|l|l|}
\hline $\mathbf{R}^{2}=\mathbf{0 , 1 2 5}$ & Énfókuszú rumináció & 0,764 & 0,266 & 0,353 & $\mathbf{2}, 876$ & 0,006 \\
\hline
\end{tabular}

4. Poszttraumás növekedés: Új életlehetőségek faktor magyarázó változói

\begin{tabular}{|l|l|c|c|c|c|c|}
\hline $\mathbf{R}^{2}=\mathbf{0 , 2 5 0}$ & $\begin{array}{l}\text { Poszttraumás } \\
\text { stressztünetek: } \\
\text { hyperarousal }\end{array}$ & 0,634 & 0,186 & 0,412 & 3,401 & 0,001 \\
\cline { 2 - 7 } & Pszichológiai jóllét & 0,801 & 0,217 & 0,447 & 3,691 & 0,001 \\
\hline
\end{tabular}

5. Poszttraumás növekedés: Spirituális változás faktor magyarázó változói

\begin{tabular}{|l|l|c|c|c|c|c|}
\hline $\mathbf{R}^{2}=\mathbf{0 , 2 9 4}$ & $\begin{array}{l}\text { Betegség idejére } \\
\text { vonatkozó társas } \\
\text { támogatás }\end{array}$ & $-0,543$ & 0,14 & $-0,783$ & $-3,89$ & $<0,001$ \\
\cline { 2 - 7 } & $\begin{array}{l}\text { Társas támogatás } \\
\text { általában }\end{array}$ & 0,396 & 0,111 & 0,718 & 3,561 & 0,001 \\
\cline { 2 - 7 } & $\begin{array}{l}\text { Poszttraumás } \\
\text { stressztünetek: } \\
\text { hyperarousal }\end{array}$ & 0,216 & 0,078 & 0,316 & 2,781 & 0,007 \\
\hline
\end{tabular}




\section{Megbeszélés}

Vizsgálatunk célja a poszttraumás növekedést befolyásoló változók vizsgálata volt gyermekkori daganatos betegségből gyógyult fiatal felnőttek és daganatos betegségből felépült gyermekek szüleinek körében. A demográfiai és betegségváltozók mellett vizsgáltuk a poszttraumás stressz tünetek, az érzelemszabályozás, a pszichológiai jóllét, az általános és betegségre vonatkozó társas támogatás mértékét is mind a szülők, mint a gyógyult fiatal felnőttek csoportjában.

A szakirodalmi eredményekkel összecsengóen saját mintánkon is megjelent a poszttraumás növekedés mind a gyógyult fiatal felnőttek, mind a szülők több, mint 90\%-ánál legalább a növekedés egy dimenziójában. Ez az eredmény konzisztens a szakirodalmi eredményekkel, miszerint a súlyos betegség tapasztalata és a traumával való küzdelem pozitív következményekkel is járhat (Arpawong és mtsai, 2013; Barakat és mtsai, 2006; Gianinazzi és mtsai, 2016). A gyógyult fiatal felnőttek áltagolt PTN összpontszáma ( $\mathrm{M}=3,18 ; \mathrm{SD}=0,97 ; 95 \% \mathrm{CI}$ : 2,88-3,44) magasabb volt, mint egy amerikai vizsgálatban $(M=2,73 ; \mathrm{SD}=1,21)$ ahol átlagosan ugyancsak több mint 10 év telt el a diagnózis óta és a résztvevők különböző gyermekkori daganatos betegségeken mentek át (Yi és mtsai, 2015). Ugyanakkor a gyógyult fiatal felnőttek átlagolt összpontszáma alacsonyabb volt, mint például egy melldaganatos mintán $(\mathrm{M}=4,51 ; \mathrm{SD}=0,92)$ (Brunet, McDonough, Hadd, Crocker, \& Sabiston, 2010), de magasabb, mint egy gyomor daganatos mintán (Sim, Lee, Kim, \& Kim, 2015) mért eredmény $(M=2,9 ; S D=1,2)$. A fiatal felnőttek mintáján - hasonlóan más vizsgálatokhoz (Gianiazzi és mtsai, 2016; Yi és mtsai, 2015) - a poszttraumás növekedés faktorai közül az Élet értékelése és a Kapcsolatok terén bekövetkező változások voltak a legmarkánsabbak, ugyanakkor fontos megemlíteni, hogy a Személyes eró és az Új életlehetőségek faktor szorosan követte az első kettőt (az átlagpontszám mind a négy faktor tekintetében 3 felett volt). Jelentősen alacsonyabb pontszámot csak a Spiritualitás faktor mutatott a fiatal felnőttek mintáján. Ennek hátterében felmerülhetnek kulturális különbségek; meghatározó lehet, hogy a gyermek milyen vallási kontextusban nevelkedett (Kilmer és mtsai, 2009). Emellett az is jelentős tényező lehet, hogy a betegség idején milyen kognitív fejlettségi szinten volt a gyermek (Hendricks-Ferguson, 2006). A szülők tekintetében is az Élet értékelése faktor volt a legmarkánsabb, ezt követte a Személyes eró faktor és a Kapcsolatok (átlagpontszám 3 felett), majd alacsonyabb szintú növekedést mutatva az Új életlehetóségek és a Spiritualitás faktor. A spiritualitás tekintetében fontos kiemelni, hogy azzal kapcsolatban még nem született vizsgálat, hogy a személy kiindulási (trauma előtti) spiritualitás/vallásosság szintje milyen kapcsolatban van a spirituális változással (Shaw, Joseph, \& Linley, 2005). Elképzelhető, hogy akiknél ennek a kez- 
deti szintje magasabb, ott a változás kevésbé látható. Módszertani szempontból fontos kiemelni, hogy a Spiritualitás skála nagyon kevés tételt tartalmaz és megbízhatósága is elmarad a többi skáláétól.

A fiatal felnőttek mintáján a dianóziskori életkor és a nem nem volt kapcsolatban a PTN-nel. Ennek hátterében felmerülhetnek módszertani okok (mintánkban nem volt kiegyenlített a nemek aránya, retrospektív vizsgálat révén a diagnóziskori életkor veszíthet jelentőségéből, valamint a minta elemszáma is kicsi volt, amely gyengíthette a statisztikai erót), ugyanakkor számos vizsgálatban ugyancsak nem találtak kapcsolatot ezen változók és a PTN között (Arpawong és mtsai, 2013; Turner-Sack és mtsai, 2012). A betegséggel kapcsolatos változók közül csak a diagnózis óta eltelt idó volt szignifikáns kapcsolatban a PTN-el, méghozzá negatív irányban. Azaz minél kevesebb idő telt el a diagnózis óta, annál magasabb volt a PTN mértéke. Fontos kiemelni, hogy átlagosan 16,51 év telt el a diagnózis közlése óta, s a szórás 5,6 év volt, így még azoknál is, akiknél kevesebb idő telt el, minimum 10 évról beszélhetünk. Ez az eredmény konzisztens számos, az utóbbi időben lefolytatott kutatás eredményeivel (pl. Barakat és mtsai, 2006; Yi \& Kim, 2014), ugyanakkor egy olyan kutatásban, ahol a diagnózis óta hosszabb idő telt el (10 évnél több) nem találtak kapcsolatot a PTN-el (pl. Klosky és mtsai, 2014). Longitudinális vizsgálat sem számol be szignifikáns változásról a PTN kapcsán 6, 12, 24 hónap elteltével serdülőkorban daganatos betegségen átesett mintán (Husson és mtsai, 2017).

A gyógyult fiatal felnőttek mintáján az általános társas támogatás, a pozitív érzelmekre vonatkozó elfojtás, az emlékbetörések és a jóllét maradtak meg szignifikáns magyarázó változók. A modell a poszttraumás növekedés varianciájának 50\%-t magyarázta, amely nagyon magas arány összevetve a szakirodalmi eredményekkel (pl.: Yi és mtsai, 2015-ös vizsgálatában 9,5\%-t). A ruminatív gondolkodást mérő, általunk használt kérdőív (Feldman és mtsai, 2008) a pozitív érzelmi állapotokra adott válaszok alapján különítette el az érzelemfókuszú és az énfókuszú ruminációt és a pozitív érzelmekre vonatkozó elfojtást. A pozitív érzelmekre vonatkozó elfojtás kapcsolatban lehet a trauma integrálásával kapcsolatos kognitív átstrukturálási (Calhoun \& Tedeschi, 2006) folyamattal. A súlyos betegség tapasztalata megrengeti a személy abba vetett hitét, hogy vele csak jó dolgok történhetnek, amely egy reálisabb világképhez segíthet hozzá, már nem gondolja azt, hogy vele csak jó dolgok fognak történni, óvatosabban áll a pozitív életeseményekhez is. Feldman és munkatársai (2008) eredeti kutatásukban azt találták, hogy a pozitív érzelmek elfojtása annak lehet az eszköze, hogy a személy fenntartsa saját világának kiszámíthatóság és stabilitás-érzését. Ugyanakkor fennáll a veszélye patológiák kialakulásának is, az önbizalom csökkenésével is együttjárhat ez a fajta érzelemszabályozási módszer (Feldman és mtsai, 2008). Fontos azonban megjegyezni, hogy a PTN faktoraira vonatkozó reg- 
ressziós vizsgálatok azt mutatták ki, hogy a pozitív érzelmekre vonatkozó elfojtásnak csak az Élet értékelése és az Ujj életlehetőségek tekintetében volt szerepe. Elképzelhető, hogy a személynek már kevésbé lesz szüksége végletes pozitív érzelmekre és eseményekre, ahhoz, hogy megbecsülje az életet, apróbb dolgoknak is tud örülni. Esetleg a pozitív érzelmek elfojtása segítségével próbálja a személy önmagát megkíméli a további csalódásoktól. Emellett, a stabilitás biztonsága hozzásegíthet az élet fokozottabb megbecsüléséhez és az élet adta lehetőségek szorongásmentesebb kipróbálásához, mivel a személy már tudja, hogy történhetnek vele rossz dolgok is.

Az emlékbetörések tekintetében fontos kiemelni, hogy azok nem csak a betegség traumájával kapcsolatos betörő gondolatokat, hanem jövőre irányuló, a betegség esetleges kiújulásával és betegséggel kapcsolatos félelmeket is tartalmazhatnak (Kangas és mtsai, 2002). Ezeknek a tüneteknek a jelenléte fenntarthatja a trauma észlelt veszélyét, amely a ruminációs folyamatokon és a társas támogatáson keresztül hathat a poszttraumás növekedésre (Meyerson, Grant, Carter, \& Kilmer, 2011: gyermekkori traumán átesett személyek poszttraumás növekedésének kialakulását magyarázó modellje). Érdekes lenne ennek fényében azt is látni, hogy - a poszttraumás növekedés irodalmában az utóbbi idóben kiemelkedett, hatodik faktor (Stanton, Bower, \& Low, 2006) - az egészségmagatartásban bekövetkező pozitív változások, az egészség fokozottabb értékelése, milyen kapcsolatban lehet az emlékbetörések gyakoriságával.

A jóllét tekintetében a WHO 5 tételes kérdőívének eredeti validáló tanulmányában (Susánszky és mtsai, 2006) a 18-44 éves korosztály átlaga 8,5 pont volt, míg jelen mintánkban ez az eredmény 8,65 lett, amely azt jelzi, hogy a gyermekkori daganatos betegséget túléló fiatal felnőttek életminősége nem tér el az életkori, populációs átlagtól. Ezt szakirodalmi eredmények is megerősítik (pl.: Kamibeppu és mtsai, 2010). Fontos azonban megjegyezni, hogy vizsgálati személyeink diagnózisa óta átlagosan 16,51 év telt el, amely magyarázhatja a jólléttel kapcsolatos átlagos eredményeket. A PTN a gyógyult fiatal felnőttek esetében egyértelmú és erős kapcsolatot mutatott a jólléttel, a PTN faktorait egyenként vizsgálva is (csak a Spiritualitásban nem volt szerepe). Ugyanakkor a jóllét szerepe magyarázó modellünkben sok kérdést vet fel. Vajon a PTN vezet-e jobb jólléthez (például melldaganatos nők esetén.: Morill és mtsai, 2008) vagy a pozitívabb családi kapcsolatok vannak hatással a jóllétre (például gyógyult daganatos gyermekek esetén.: Orbuch, Parry, Chesler, Fritz, \& Repetto, 2005)? Esetleg reciprok kapcsolatról beszélhetünk, hiszen a stabil jóllét állapotában hajlamosabb lehet az ember pozitívabb változásokat meglátni, amely visszahat a jóllétról alkotott elképzelésére. A gyermekkori daganatos betegségból gyógyult személyek vizsgálatában ez a terület még igencsak elhanyagolt, leginkább a daganatos 
beteg és gyógyult fiatal felnőttek jóllétével (pl. Quinn, Goncalves, Sehovic, Bowman, \& Reed, 2015) és poszttraumás tüneteivel foglalkoznak a kutatások, a PTN tekintetében még kevés vizsgálat született.

A szülők esetében a poszttraumás növekedés szempontjából a poszttraumás stressztüneteknek és az összes érzelemszabályozási formának is nagy szerepe volt, ugyanakkor a végső modellben csak a hyperarousal, az énfókuszú rumináció és a jóllét maradtak. A modell megerósíti azt az eredeti elképzelést (amely a gyógyult fiatal felnőtteknél is így történt), hogy a poszttraumás növekedés kialakulásához szükség van a distressz jelenlétére (Calhoun \& Tedeschi, 2006). Egy longitudinális kutatás szerint a szülők által átélt stressztünetek (főleg jellegükből adódóan az emlékbetörések és a hyperarousal) nagyobb mértékben fennmaradhatnak az idó múlásával is (Pöder, Ljungman, \& von Essen, 2008), ami magyarázhatja azt, hogy - jelen vizsgálatunkban - még átlagosan 8,1 év elteltével is markánsak a szülő́knél, amikor fel kell idézniük a traumát. Emellett a szülők felnőttekre jellemző kognitív kapacitása miatt objektívebben meg tudják ítélni, hogy milyen súlyos a betegség életet fenyegetó jellege (Kazak és mtsai, 2004; Landolt, Vollrath, Ribi, Gnehm, \& Sennhauser, 2003), s jobban tartanak a kiújulástól is. Ez felveti a gondolatot, hogy egy daganatos beteg gyermek szülöjének lenni még traumatikusabb, mint átélni a betegséget. Míg a gyógyult fiatal felnőtteknél a társas támogatásnak volt szerepe, addig a szülőknél az önmagukba és saját erejükbe vetett hit volt fontos hatótényező. Az énfókuszú rumináció során a személy visszatérő automatikus gondolatai pozitív énképével kapcsolatosak, amely segíthet a nehéz helyzetek elviselésében. A jóllét szerepe a szülők esetében is megjelenik a PTN kapcsán, amelynek hátterében a fenyegetettség csökkenése (gyógyult gyermek) állhat. A szülőkkel kapcsolatban ugyanakkor felmerül a kérdés, hogy a vizsgált változók miért csak 26\%-t magyarázták a PTN-nek. Elképzelhető, hogy a szülők poszttraumás növekedése szempontjából több, a gyermekkel kapcsolatos tényezőt lenne érdemes vizsgálni és diádikus elemzéseket végezni.

A gyógyult fiatal felnőttek és a szülők csoportjának eredményeit összehasonlítva megállapítható, hogy a jóllétnek mindkét csoportban szerepe volt a PTN kapcsán. Az érzelemszabályozási folyamatok tekintetében fontos különbség ugyanakkor, hogy a gyógyult fiatal felnőtteknél a pozitív érzelmekre irányuló elfojtás, míg a szülőknél az énfókuszú ruminációnak volt nagy szerepe. Ennek hátterében állhat, hogy a betegség idején a gyermek és a szülő eltérő kognitív fejlettségi szinten éli át a traumát. A szülók a felnőttekre jellemző, érett kognitív kapacitással jobban felmérik a betegség objektív életet veszélyeztetô jellegét (Yalug és mtsai, 2011), így kénytelenek azzal teljes valójában szembenézni, mind a mellett, hogy közben gyermekük támogatása az elsődleges feladatuk. Szakirodalmi eredmények is rámutatnak, 
hogy a gyermekek a legerősebb támogatást a szülőktől élik meg (Trask és mtsai, 2003), amely ugyanakkor a szülő számára további stresszforrás. Ilyenformán a szülők önmagukba, saját erejükbe vetett hite, érthetően fontos hatótényező lehet, mind a traumával való megküzdés, mind gyermeke támogatása, mind a PTN szempontjából. Ezt erősíti az az eredményünk is, hogy a szülő́k csoportjában a PTN Személyes erő faktorára szignifikáns hatása csak az énfókuszú ruminációnak volt. A gyógyult fiatal felnőttek átlagéletkora a betegség idején 10,77 év volt, azonban a mintába olyan vizsgálati személyek is bekerültek, akik a betegség idején 0-3 év közötti életkorban voltak, így fejlődéspszichológiai szempontból kevésbé lehettek érintettek a betegség traumatizáló jellegében, szemben a szülőkkel. A gyermekek önreflexiós szintje, belső reprezentációik és alaphiedelmeik, valamint alapvetó munkamódjuk még csak kialakulóban van ebben az életkorban, így az érzelemszabályozás kevéssé tudatos még (Kilmer és mtsai, 2014). Valószínúsíthető, hogy a gyerekek a betegség idején nem érték még el azt az absztrakciós szintet a gondolkodásban, amely a trauma ruminatív feldolgozásában segíthetne, ugyanakkor jelenlegi átlagéletkoruk (27,5 év) már feltételezi a felnőttekre jellemző kognitív fejlettségi szintet. A diagnózis óta azonban átlagosan 16 év telt el, így a vizsgálat retrospektív jellege megnehezíti ennek a gondolati szálnak a magyarázatát. Egy új vizsgálati irány (Nashiro, Shakaki, \& Mather, 2012) alapján ugyanakkor elképzelhetó, hogy az idősebb felnőttek érzelemszabályozási funkciói javulnak az életkorral, amelynek a hátterében az áll, hogy a pozitív ingereket jobban feldolgozzák, mint a negatívakat (figyelmi és memória funkciók változása). Ennek megfelelóen, amíg a fiatalabbaknál hangsúlyosabbak lehetnek a pozitív érzelmek elfojtására irányuló érzelemszabályozási technikák, addig az idősebb szülőknél a pozitív hatást erősítő rumináció válhat meghatározóvá.

Kapott eredményeinket megfelelő óvatossággal érdemes értelmezni, mivel a vizsgált változókat önbeszámolós kérdőívekkel mértük fel, s a minta elemszáma nem volt túl magas, ami ebben a betegségpopulációban általános jelenség. Emellett fontos szempont az is, hogy a részvétel önkéntes volt, így a minta nem reprezentatív. Ugyanakkor az, hogy különböző nem egészségügyi szervezeteken keresztül jutottunk el a vizsgálati személyekig, nagyobb heterogenitást eredményezhetett. Emellett azonban felmerül, hogy nem tapasztalhattunk-e csoporthatást a poszttraumás növekedés magas szintjében. Kérdés, hogy azok a vizsgálati személyek, akik nem egészségügyi, segítő szervezetekhez fordulnak, nem nyitottabbak-e alaphelyzetben a külső segítség elfogadására. Vizsgálatunk korlátja az is, hogy a különböző betegségcsoportok megjelenése nem volt kiegyenlített a mintában, emellett a betegséggel kapcsolatos változókat kevéssé tudtuk vizsgálni. Fontos lenne a diagnózis észlelt súlyosságát is felmérni, amely hasznos információkkal szolgálna a fenyegetettség mértékéról. Felmerül az a kérdés is, hogy vajon minden vizsgálati személy traumának tekintette-e a betegséget. 
A fenti limitációk mellett azonban kutatásunk hasznos információkkal szolgál a jövőbeni intervenciók tervezése szempontjából. Az eredményekből egyértelmú, hogy érdemes lenne a gyermekkori daganatos betegségen átesett személyeket nemcsak egyénileg, de a családi múködés tekintetében is segíteni, a kezelés és a lábadozás alatt szociális támogatási rendszerüket erősíteni és facilitálni, valamint segíteni a trauma integrálását kognitív terápiás eszközökkel életkoruknak megfelelően, amennyiben a klinikus adekvátnak látja. Mindezt természetesen a stressztünetek kezelése mellett. A külföldi gyakorlatban születtek is erre vonatkozó intervenciós protokollok (Brier, Schwartz, \& Kazak, 2015; Kazak, 2005).

\section{Irodalom}

American Psychiatric Association. (2013). Diagnostic and statistical manual of mental disorders (5th ed.). Arlington, VA: American Psychiatric Publishing

American Psychiatric Association (1994). Diagnostic and statistical manual of mental disorders (4th ed.). Arlington, VA: American Psychiatric Publishing

Armstrong, G. T., Liu, Q., Yasui, Y., Neglia, J. P., Leisenring, W., Robison, L. L., et al. (2009). Late mortality among 5-year survivors of childhood cancer: a summary from the Childhood Cancer Survivor Study. Journal of Clinical Oncology, 27(14), 23-28.

Arpawong, T. E., Oland, A., Milam, J. E., Ruccione, K., \& Meeske, K. A. (2013). Posttraumatic growth among an ethnically diverse sample of adolescent and young adult cancer survivors. Psycho-Oncology, 22(10), 2235-2244.

Barakat, L.P., Alderfer, M.A., \& Kazak, A. E. (2006). Posttraumatic growth in adolescent survivors of cancer and their mothers and fathers. Journal of Pediatric Psychology, 31(4), 413-419.

Bech, P., Gudex, C., \& Johansen, K. S. (1996). The WHO (Ten) well-being index: validation in diabetes. Psychotherapy and Psychosomatics, 65(4), 183-190.

Best, M., Streisand, R., Catania, L., \& Kazak, A.E. (2001). Parental distress during pediatric leukemia and posttraumatic stress symptoms (PTSS) after treatment ends. Journal of Pediatric Psychology, 26(5), 299-307.

Bijttebier, P., Raes, F., Vasey, M. W., \& Feldman, G. C. (2012). Responses to positive affect predict mood symptoms in children under conditions of stress: a prospective study. Journal of Abnormal Child Psychology, 40(3), 381-389.

Brier, M. J., Schwartz, L. A., \& Kazak, A. E. (2015). Psychosocial, health-promotion, and neurocognitive interventions for survivors of childhood cancer: A systematic review. Health Psychology, 34(2), 130-148.

Bruce, M., Gumley, D., Isham, L., Fearon, P., \& Phipps, K. (2011). Posttraumatic stress symptoms in childhood brain tumour survivors and their parents. Child: Care, Health and Development, 37(2), 244-251.

Bruce, M. (2006). A systematic and conceptual review of posttraumatic stress in childhood cancer survivors and their parents. Clinical Psychology Review, 26(3), 233-256.

Brunet, J., McDonough, M. H., Hadd, V., Crocker, P. R., \& Sabiston, C. M. (2010). The Posttraumatic Growth Inventory: An examination of the factor structure and invariance among breast cancer survivors. Psycho-Oncology, 19(8), 830-838.

Bussell, V. A. \& Naus, M. J.(2010). A longitudinal investigation of coping and posttraumatic growth in breast cancer survivors. Journal of Psychosocial Oncology, 28(1), 61-78. 
Caldwell, R. A., Pearson, J. L., \& Chin, R. J. (1987). Stress-moderating effects: Social support in the context of gender and locus of control. Personality and Social Psychology Bulletin, 13(1), 5-17.

Calhoun, L. G. \& Tedeschi, R. G. (2006). The foundations of posttraumatic growth: An expanded framework. In L.G. Calhoun \& R.G. Tedeschi (Eds.) Handbook of posttraumatic growth - Research and practice. (3-23). London: Lawrence Erlbaum Associates

Devine, K. A., Reed-Knight, B., Loiselle, K. A., Fenton, N., \& Blount, R. L. (2010). Posttraumatic growth in young adults who experienced serious childhood illness: A mixed-methods approach. Journal of Clinical Psychology in Medical Settings, 17(4), 340-348.

Ekim, A., \& Ocakci, A. F. (2015). Relationship between posttraumatic growth and perceived social support for adolescents with cancer. Journal of Hospice E Palliative Nursing, 17(5), 450-455.

Erickson, S. J., \& Steiner, H. (2000). Trauma spectrum adaptation: somatic symptoms in long-term pediatric cancer survivors. Psychosomatics, 41(4), 339-346.

Feldman, G. C., Joormann, J., \& Johnson, S. L. (2008). Responses to positive affect: A selfreport measure of rumination and dampening. Cognitive Therapy and Research, 32(4), 507-525.

Gianinazzi, M. E., Rueegg, C. S., Vetsch, J., Lüer, S., Kuehni, C. E., Michel, G., et al. (2016). Cancer's positive flip side: posttraumatic growth after childhood cancer. Supportive Care in Cancer, 24(1), 195-203.

Gunst, D. C. M., Kaatsch, P., \& Goldbeck, L. (2016). Seeing the good in the bad: which factors are associated with posttraumatic growth in long-term survivors of adolescent cancer? Supportive Care in Cancer, 24(11), 4607-4615.

Hendricks-Ferguson, V. (2006). Relationships of age and gender to hope and spiritual wellbeing among adolescents with cancer. Journal of Pediatric Oncology Nursing, 23(4), 189-199.

Horowitz, M., Wilner, N., \& Alvarez, W. (1979). Impact of Event Scale: a measure of subjective stress. Psychosomatic Medicine, 41(3), 209-218.

Hungerbuehler, I., Vollrath, M. E., \& Landolt, M. A. (2011). Posttraumatic growth in mothers and fathers of children with severe illnesses. Journal of Health Psychology, 16(8), 1259-1267.

Husson, O., Zebrack, B., Block, R., Embry, L., Aguilar, C., Hayes-Lattin, B., et al. (2017). Posttraumatic growth and well-being among adolescents and young adults (AYAs) with cancer: a longitudinal study. Supportive Care in Cancer, 25(9), 2881-2890.

Kamibeppu, K., Sato, I., Honda, M., Ozono, S., Sakamoto, N., Iwai, et al. (2010). Mental health among young adult survivors of childhood cancer and their siblings including posttraumatic growth. Journal of Cancer Survivorship, 4(4), 303-312.

Kangas, M., Henry, J. L., \& Bryant, R. A. (2002). Posttraumatic stress disorder following cancer: A conceptual and empirical review. Clinical Psychology Review, 22(4), 499-524.

Kazak, A. E., Kassam-Adams, N., Schneider, S., Zelikovsky, N., Alderfer, M. A., \& Rourke, M. (2005). An integrative model of pediatric medical traumatic stress. Journal of Pediatric Psychology, 31(4), 343-355.

Kazak, A. E., Alderfer, M., Rourke, M. T., Simms, S., Streisand, R., \& Grossman, J. R. (2004). Posttraumatic stress disorder (PTSD) and posttraumatic stress symptoms (PTSS) in families of adolescent childhood cancer survivors. Journal of Pediatric Psychology, 29(3), 211-219.

Kazak, A. E. (1998). Posttraumatic distress in childhood cancer survivors and their parents. Medical and Pediatric Oncology Supplement: The Official Journal of SIOP - International Society of Pediatric Oncology (Societé Internationale d>Oncologie Pédiatrique, 30(S1), 60-68.

Kilmer, R. P., Gil-Rivas, V., Griese, B., Hardy, S. J., Hafstad, G. S., \& Alisic, E. (2014). Posttraumatic growth in children and youth: clinical implications of an emerging research literature. American Journal of Orthopsychiatry, 84(5), 506. 
Kilmer, R. P., Gil \& Rivas, V., Tedeschi, R. G., Cann, A., Calhoun, L. G., Buchanan, T., et al. (2009). Use of the revised posttraumatic growth inventory for children. Journal of Traumatic Stress, 22(3), 248-253.

Kilmer, R. P., \& Gil \& Rivas, V. (2010). Exploring posttraumatic growth in children impacted by Hurricane Katrina: Correlates of the phenomenon and developmental considerations. Child Development, 81(4), 1211-1227.

Kilmer R.P. (2006). Resilience and posttraumatic growth in children. In L.G. Calhoun \& R.G. Tedeschi (Eds.). Handbook of posttraumatic growth: Research and practice. (264-288). London: Lawrence Erlbaum Associates

Klosky, J. L., Krull, K. R., Kawashima, T., Leisenring, W., Randolph, M. E., Zebrack, et al. (2014). Relations between posttraumatic stress and posttraumatic growth in long-term survivors of childhood cancer: A report from the Childhood Cancer Survivor Study. Health Psychology, 33(8), 878-882.

Kocsis-Bogár, K., Miklósi, M., \& Perczel Forintos, D. (2012). Az Események Hatása Kérdőív magyar változatának pszichometriai vizsgálata. Psychiatria Hungarica. 27(4), 245-254.

Kopp, M., Skrabski, Á., \& Neukem, L. (1992). Magyar lelkiállapot. Budapest: Végeken Alapítvány

Kovács, É., Balog, P., \& Preisz, L. (2012). A Poszttraumás Növekedésérzés Kérdőív pszichometriai mutatói hazai mintán. Mentálhigiéné és Pszichoszomatika, 13(1), 57-84.

Landolt, M. A., Vollrath, M., Ribi, K., Gnehm, H. E., \& Sennhauser, F. H. (2003). Incidence and associations of parental and child posttraumatic stress symptoms in pediatric patients. Journal of Child Psychology and Psychiatry, 44(8), 1199-1207.

Manne, S., Ostroff, J., Winkel, G., Goldstein, L., Fox, K., \& Grana, G. (2004). Posttraumatic growth after breast cancer: Patient, partner, and couple perspectives. Psychosomatic Medicine, 66(3), 442-454.

McDonnell, G. A., Pope, A. W., Schuler, T. A., \& Ford, J. S. (2018). The relationship between cancer-related worry and posttraumatic growth in adolescent and young adult cancer survivors. Psycho-Oncology, 27(9), 2155-2164.

Meyerson, D. A., Grant, K. E., Carter, J. S., \& Kilmer, R. P. (2011). Posttraumatic growth among children and adolescents: A systematic review. Clinical Psychology Review, 31(6), 949-964.

Morrill, E. F., Brewer, N. T., O`Neill, S. C., Lillie, S. E., Dees, E. C., Carey, L. A., et al. (2008). The interaction of post-traumatic growth and post-traumatic stress symptoms in predicting depressive symptoms and quality of life. Psycho-Oncology, 17(9), 948-953.

Nashiro, K., Sakaki, M., \& Mather, M. (2012). Age differences in brain activity during emotion processing: Reflections of age-related decline or increased emotion regulation. Gerontology, 58(2), 156-163.

Nyulászi, A., \& Rigó, A. (2014). Tapasztalatok HIV-specifikus életminőség kérdőívvel magyar mintán. Alkalmazott Pszichológia, 14(4), 89-101.

Orbuch, T. L., Parry, C., Chesler, M., Fritz, J., \& Repetto, P. (2005). Parent-child relationships and quality of life: Resilience among childhood cancer survivors. Family Relations, 54(2), 171-183.

Perczel-Forintos, D., Ajtay, Gy., Barna, Cs., Kiss, Zs., \& Komlósi, S. (Szerk.) (2012). Kérdőívek és becslőskálák a klinikai pszichológiában. Budapest: Semmelweis Kiadó.

Picoraro, J. A., Womer, J. W., Kazak, A. E., \& Feudtner, C. (2014). Posttraumatic growth in parents and pediatric patients. Journal of Palliative Medicine, 17(2), 209-218.

Pöder, U., Ljungman, G., \& von Essen, L. (2008). Posttraumatic stress disorder among parents of children on cancer treatment: a longitudinal study. Psycho-Oncology 17(5), $430-437$. 
Quinn, G. P., Gonçalves, V., Sehovic, I., Bowman, M. L., \& Reed, D.R. (2015). Quality of life in adolescent and young adult cancer patients: a systematic review of the literature. Patient Related Outcome Measures, 6, 19-51.

Rigó, A., \& Zsigmond, O. (2015). A szomatikus betegség, mint trauma. In E.Cs. Kiss \& H.Sz. Makó (Szerk.), Gyász, krízis, trauma és a megküzdés lélektana (291-312). Pécs: Pro Pannónia Kiadó

Shaw, A., Joseph, S., \& Linley, P. A. (2005). Religion, spirituality, and posttraumatic growth: A systematic review. Mental Health Religion and Culture, 8(1), 1-11.

Stanton, A. L., Bower, J. E., \& Low, C. A. (2006). Posttraumatic growth after cancer. In L. G. Calhoun \& R. G. Tedeschi (Eds.), Handbook of posttraumatic growth: Research and practice (138-175). New Jersey: John Wiley\& Sons

Sim, B. Y., Lee, Y. W., Kim, H., \& Kim, S. H. (2015). Post-traumatic growth in stomach cancer survivors: Prevalence, correlates and relationship with health-related quality of life. European Journal of Oncology Nursing, 19(3), 230-236.

Sumalla, E. C., Ochoa, C., \& Blanco, I. (2009). Posttraumatic growth in cancer: reality or illusion?. Clinical Psychology Review, 29(1), 24-33.

Susánszky, É., Konkolÿ Thege, B., Stauder, A., \& Kopp, M. (2006). A WHO Jól-lét Kérdőív rövidített (WBI-5) magyar változatának validálása a Hungarostudy 2002 országos lakossági egészségfelmérés alapján. Mentálhigiéné és Pszichoszomatika, 7(3), 247-255.

Tandari-Kovács, M. (2010). Érzelmi megterhelődés, lelki kiégés az egészségügyi dolgozók körében. (Doktori értekezés) Budapest: Semmelweis Egyetem.

Tedeschi, R. G., Calhoun, L. G., \& Cann, A. (2007). Evaluating resource gain: Understanding and misunderstanding posttraumatic growth. Applied Psychology, 56(9), 396-406.

Tedeschi, R. G., \& Calhoun, L. G. (2004). Posttraumatic growth: Conceptual foundations and empirical evidence. Psychological Inquiry, 15(1), 1-18.

Tedeschi, R. G., \& Calhoun, L.G. (1996). The Posttraumatic Growth Inventory: Measuring the positive legacy of trauma. Journal of Traumatic Stress, 9(3), 455-471.

Trask, P. C., Paterson, A. G., Trask, C. L., Bares, C. B., Birt, J., \& Maan, C. (2003). Parent and adolescent adjustment to pediatric cancer: associations with coping, social support, and family function. Journal of Pediatric Oncology Nursing, 20(1), 36-47.

Turner-Sack, A. M., Menna, R., \& Setchell, S. R. (2012). Posttraumatic growth, coping strategies, and psychological distress in adolescent survivors of cancer. Journal of Pediatric Oncology Nursing, 29(2), 70-79.

Ward, E., DeSantis, C., Robbins, A., Kohler, B., \& Jemal, A. (2014). Childhood and adolescent cancer statistics, 2014. Ca: A Cancer Journal for Clinicians, 64(2), 83-103.

Weiss, D. S., \& Marmar, C. R. (1997). The Impact of Event Scale-Revised. In J. P. Wilson \& T. M. Keane (Eds.) Assessing psychological trauma and PTSD (pp. 399-411). New York: The Guilford Press.

Yalug, I., Tufan, A.E., Doksat, K., \& Yaluğ, K. (2011). Post-traumatic stress disorder and post-traumatic stress symptoms in parents of children with cancer: A review. Neurology, Psychiatry and Brain Research, 17(1), 27-31.

Yi, J., Zebrack, B., Kim, M.A., \& Cousino, M. (2015). Posttraumatic growth outcomes and their correlates among young adult survivors of childhood cancer. Journal of Pediatric Psychology, 40(9), 981-991.

Yi, J., \& Kim, M. A. (2014). Postcancer experiences of child- hood cancer survivors: How is posttraumatic stress related with posttraumatic growth? Journal of Traumatic Stress, 27, 461-467. 
Zebrack, B., Kwak, M., Salsman, J., Cousino, M., Meeske, K., Aguilar, C., et al. (2015). The relationship between posttraumatic stress and posttraumatic growth among adolescent and young adult (AYA) cancer patients: Posttraumatic growth in adolescents/young adults with cancer. Psycho-Oncology, 24(2), 162-168.

Zebrack, B. J., \& Chesler, M. A. (2002). Quality of life in childhood cancer survivors. PsychoOncology, 11(2), 132-141.

Zwahlen, D., Hagenbuch, N., Carley, M. I., Jenewein, J., \& Buchi, S. (2010). Posttraumatic growth in cancer patients and partners - effects of role, gender and the dyad on couples posttraumatic growth experience. Psycho-Oncology, 19(1), 12-20.

Zsigmond, O., Rigó, A., \& Bányai, É. (2017). A daganatos betegségek Janus arca: a poszttraumás növekedés jelensége. Mentálhigiéné és Pszichoszomatika, 18(2), 149-170.

\section{Szerzói munkamegosztás}

Zsigmond Orsolya a tanulmány értelmi szerzője, a szakirodalmi áttekintés irányának kidolgozója és a szakirodalmi adatgyuujtés és a statisztikai elemzések lefolytatója, valamint a kézirat megszövegezője. Rigó Adrien a kutatás irányának kialakításában, lefolytatásában és feltételeinek megteremtésében, valamint az eredmények értelmezésében és a cikk szövegének végső kialakításában nyújtott segítséget.

\section{Nyilatkozat érdekütközésról}

A szerzők ezúton kijelentik, hogy esetükben nem állnak fenn érdekütközések.

\section{Posttraumatic growth among young adult survivors of childhood cancer and parents of childhood cancer survivors}

Theoretical background: Childhood cancer is a serious, traumatic experience for the child and for the parents of the child. However, in addition to negative psychological consequences, in a lot of cases positive changes, posttraumatic growth (PTG) can also occur in the experience of the child and the parents. Aim: The aim of this study was to explore the factors affecting posttraumatic growth in young adult survivors of childhood cancer and the parents of childhood cancer survivors. Methods: In our retrospective study, 53 young adult survivors of childhood cancer ( 17 male and 36 female, mean age $=27.5$ years, $S D=$ 5.4 years) and 112 parents ( 9 male and 103 female, mean age $=44.9$ years, $S D=6.7$ years) participated. We examined the relationship between PTG and demographic (gender, age, disease variables (time since diagnosis, age of diagnosis, risk of diagnosis) and psychosocial factors (social support, emotional regulation, well-being, posttraumatic stress symptoms) using descriptive, comparative, correlational and regression analysis. Results: The results confirmed that more than $90 \%$ of young adults and parents experienced PTG at least at minimal level at least in one dimension of growth. In the group of young adult survivors $50 \%$ of PTG variance was explained by social support, intrusive thoughts from 
posttraumatic stress symptoms, dampening of positive emotions, and well-being. In the group of parents hyperarousal, self-focused rumination and well-being explained $26.5 \%$ of PTG variance. Conclusions: The results confirm that in the explanation of PTG different variables are working in a complex relationship system. The results of our study show that in the planning of clinical psychological interventions, in addition to individual treatment of negative symptoms associated with the disease, the involvement of the family, the improvement of social factors and various cognitive therapeutic tools could be important for the integration of trauma.

Keywords: posttraumatic growth, childhood cancer, posttraumatic stress symptoms, rumination, social support

A cikk a Creative Commons Attribution 4.0 International License (https:/ / creativecommons.org/ licenses/by/4.0/) feltételei szerint publikált Open Access közlemény, melynek szellemében a cikk bármilyen médiumban szabadon felhasználható, megosztható és újraközölhető, feltéve, hogy az eredeti szerző és a közlés helye, illetve a CC License linkje és az esetlegesen végrehajtott módosítások feltüntetésre kerülnek. (SID_1) 